\title{
Glacial and Periglacial Environments
}

Link to publication record in Manchester Research Explorer

\section{Citation for published version (APA):}

Hughes, P. D., \& Woodward, J. C. (Ed.) (2009). Glacial and Periglacial Environments. In The Physical Geography of the Mediterranean Basin (1st ed., pp. 353-383). Oxford University Press.

\section{Published in:}

The Physical Geography of the Mediterranean Basin

\section{Citing this paper}

Please note that where the full-text provided on Manchester Research Explorer is the Author Accepted Manuscript or Proof version this may differ from the final Published version. If citing, it is advised that you check and use the publisher's definitive version.

\section{General rights}

Copyright and moral rights for the publications made accessible in the Research Explorer are retained by the authors and/or other copyright owners and it is a condition of accessing publications that users recognise and abide by the legal requirements associated with these rights.

\section{Takedown policy}

If you believe that this document breaches copyright please refer to the University of Manchester's Takedown Procedures [http://man.ac.uk/04Y6Bo] or contact uml.scholarlycommunications@manchester.ac.uk providing relevant details, so we can investigate your claim.

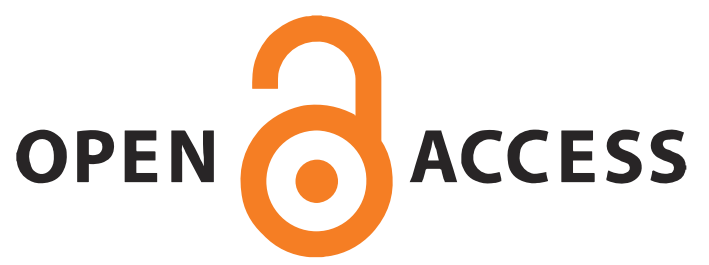




\title{
12 Glacial and Periglacial Environments
}

\author{
Philip Hughes and Jamie Woodward
}

\section{Introduction}

Traditionally, glacial and periglacial geomorphology has not featured prominently in discussions about the physical geography of the Mediterranean basin. It is now clear, however, that on numerous occasions during the Pleistocene, and to a lesser extent during the Little Ice Age (LIA), glacial and periglacial activity was widespread in many of the region's mountain ranges (Hughes et al. 2006a; Hughes and Woodward 2008). Even today, small glaciers and active periglacial features can be found on the highest peaks. Many mountain landscapes in the Mediterranean basin are therefore the product of glacial and periglacial processes that have fluctuated in intensity and spatial extent through the Quaternary. Glacial processes are defined here as those occurring as a result of dynamic glacier ice. The periglacial zone is sometimes defined as non-glacial areas where the mean annual temperature is less than $3^{\circ} \mathrm{C}$ (French 1996: 20). However, cryogenic processes can be important in landform development, even in areas of shallow frost over a wide range of mean annual temperatures. Thus, the term 'periglacial' is applied here to areas characterized by cold-climate processes - where frost and nival processes are important-but where glaciers are absent.

Glacial and periglacial processes in the uplands can exert considerable influence upon geomorphological systems at lower elevations. Fluvial systems, for example, over a range of timescales have been shown to be especially sensitive to changes in sediment supply and water discharge from glaciated mountain headwaters (Gurnell and Clark 1987; Woodward et al. 2008). Nonetheless, the geomorphological impacts of glaciation are most clearly evident in the Mediterranean mountains where the erosional and depositional legacy is frequently well preserved. Cirques, glacial lakes, icescoured valleys, moraines, pronival ramparts, relict rock glaciers, and other glacial and periglacial features can be found in many Mediterranean mountain ranges (Hughes et al. 2006a). Upland limestone terrains are widespread across the Mediterranean and many of these landscapes have been shaped by a combination of glacial and karstic processes (Chapter 10). In fact, glacio-karst is probably the dominant landscape in many mountain regions, including the Dinaric Alps of Croatia/Bosnia/Montenegro (Nicod 1968), the Cantabrian Mountains of Spain (Smart 1986) and the Pindus Mountains of Greece (Waltham 1978; Woodward et al. 2004; Hughes et al. 2006b). Glaciated mountain landscapes are also found in other rock types including granite (e.g. Monte Cinto, Corsica) (Conchon 1978) and ophiolite (e.g. Mount Smolikas, Greece) (Hughes et al.2006c).

Glacial and periglacial landforms provide an important record of environmental change and can be used to reconstruct past glacial climates. This chapter examines the evidence for both past and present glacial and periglacial activity in the Mediterranean mountains and assesses its wider significance in the region. All the sites referred to in this chapter are shown in Figure 12.1 and all elevations are given in metres above sea level. This chapter is divided into three main parts. These consider, in turn, glacial and periglacial environments of the present, during the Holocene (with emphasis on the LIA), and during the cold stages of the Pleistocene. 


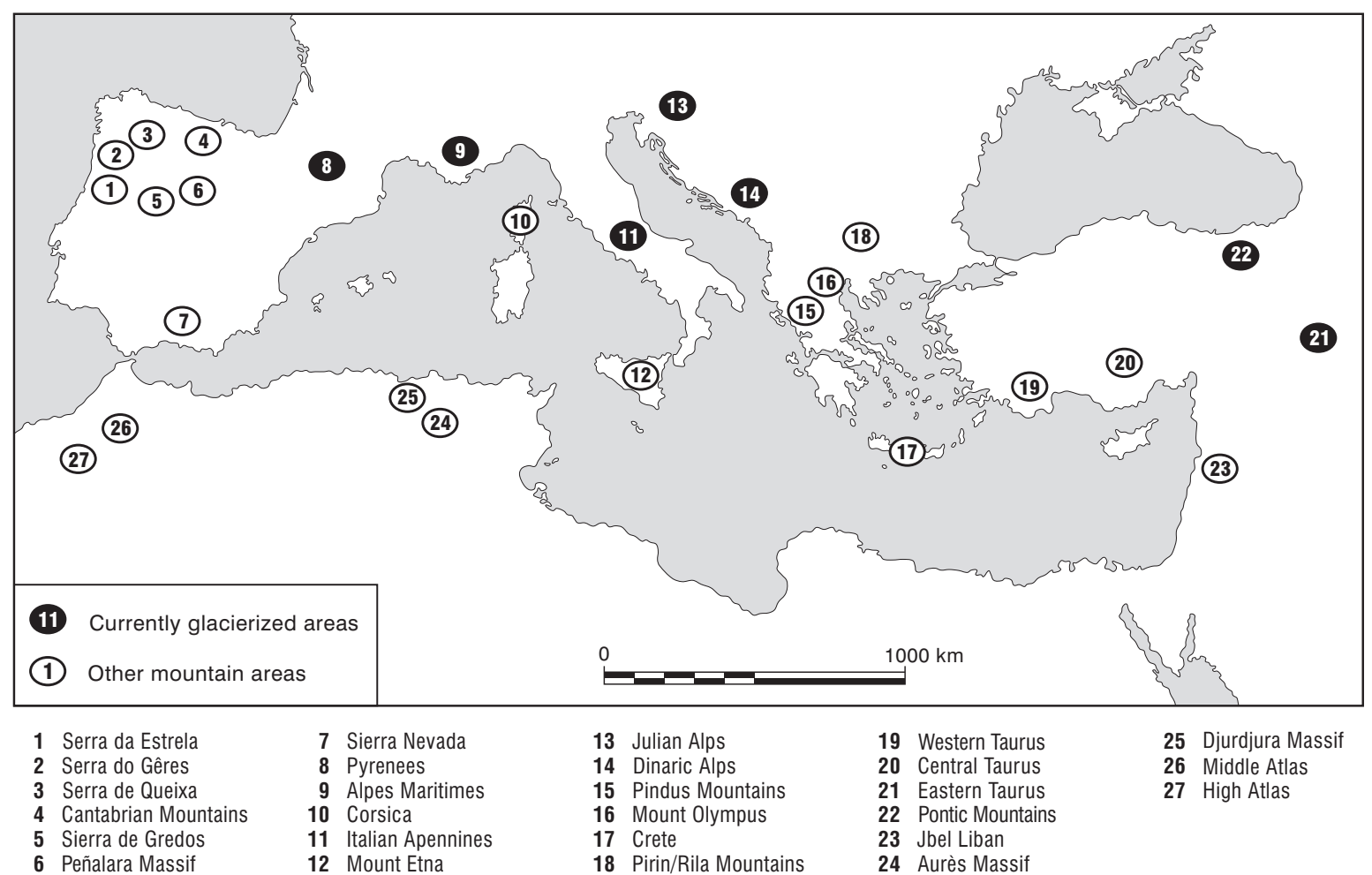

Fig. 12.1. Map of the Mediterranean showing the main mountain areas referred to in this chapter. Currently glacierized areas are indicated.

\section{Modern Glacial and Periglacial Environments}

Modern glaciers are rare in the Mediterranean because most mountains do not reach the snowline. Glaciers are present, however, under modern climatic conditions in the Pyrenees, Alpes Maritimes, Italian Apennines, Julian Alps, and in the mountains of Montenegro and Turkey (Table 12.1 and Figure 12.1). These glaciers are mainly small cirque glaciers on mountains above $2,500 \mathrm{~m}$, but extensive valley glaciers and small ice caps are present on some of the highest mountains $(>4,000 \mathrm{~m})$.

Periglacial processes are much more widespread and are active above $2,000 \mathrm{~m}$ in areas as far south as the Moroccan Atlas and at lower elevations in the northern Mediterranean. Snowfall is heavy in many of the Mediterranean mountains with most falling during the winter months between November and March (Chapter 3).

\section{Turkey}

Thirty-eight modern glaciers have been identified in the mountains of Turkey and the largest Mediterranean
TABLE 12.1. Modern glaciers in the Mediterranean

\begin{tabular}{lcclc}
\hline Mountain area & $\begin{array}{c}\text { Number } \\
\text { of } \\
\text { glaciers }\end{array}$ & $\begin{array}{c}\text { Total } \\
\text { glacier } \\
\text { area } \\
\left(\mathrm{km}^{2}\right)\end{array}$ & ELA $(\mathrm{m})$ & $\begin{array}{c}\text { Maximum } \\
\text { glacier } \\
\text { length } \\
(\mathrm{km})\end{array}$ \\
\hline Pyrenees & 41 & 11.43 & $2,320-3,005$ & 2.0 \\
Alpes Maritimes & 6 & 0.31 & 2,800 & $<0.5$ \\
Apennines & 1 & 0.045 & 2,750 & 0.4 \\
Julian Alps & 1 & 0.0303 & 2,500 & $<0.5$ \\
Turkey & $40+$ & 22.9 & $2,900-4,100$ & 4.0 \\
Montenegro & 1 & 0.05 & 2,150 & $<0.5$ \\
\hline
\end{tabular}

Sources: Based on data provided in Serrat and Ventura (1993). J. M. Grove (2004), Gellatly et al. (1994), Gabrovec (1998), Çiner (2004), Kurter and Sungur (1980), and Hughes (2007).

glaciers occur in the mountains of eastern Turkey (Akçar and Schlüchter 2005). The presence of glaciers in these mountains was noted in the nineteenth century by Ainsworth (1842) and Palgrave (1872). In 1980, glaciers covered a total area of $c .22 .9 \mathrm{~km}^{2}$ (Kurter and Sungur 1980), although almost everywhere glaciers are in retreat (Çiner 2004). Periglacial activity is also 
likely to be a major influence on modern landform development in these areas, but its effects have not been studied in detail.

Mount Ararat (Ağri Daği), a dormant stratovolcano situated in the easternmost Taurus Mountains, is the highest peak in Turkey $(5,137 \mathrm{~m})$ and is covered by an ice cap of about $10 \mathrm{~km}^{2}$. This represents the largest single ice mass on any Mediterranean mountain. The ice cap extends down to $c .4,100 \mathrm{~m}$ and has a snowline altitude of $c .4,300 \mathrm{~m}$ (Kurter and Sungur 1980). Glaciers are found on other Turkish volcanoes, including Mount Süphan (4,058 m) and Mount Erciyes (3,917 m). On Mount Süphan, several glaciers occur in the crater, the largest being on a north-facing slope with a length of $1.5 \mathrm{~km}$ (Kurter 1991; Ciner 2004). The glacier on Mount Erciyes has been the focus of studies throughout the twentieth century and is known to have retreated from a length of $700 \mathrm{~m}$ in 1905 to a length of only $380 \mathrm{~m}$ by 1983 (Sarikaya 2003; Ciner 2004). These three volcanoes are now dormant, but K-Ar isotope age dating of lavas indicate volcanic activity during the Quaternary (Yilmaz et al. 1998). Volcanic activity is therefore likely to have interacted with glacial ice, especially during cold stages when glaciers were much more extensive. Three glacial stratigraphical units have been identified on Mount Ararat and two of these are covered by volcanic deposits (ibid.), although the relationship between dated volcanic units and glacial units on Mount Ararat is not clear.

The south-eastern Taurus range (Güneydoğu Toroslar) contains the greatest concentration $(n=$ 20) of modern glaciers in Turkey and the wider Mediterranean region (Figure 12.1). These are also the most southerly glaciers in the Mediterranean basin and owe their existence to the high altitude of these mountains $(>4,000 \mathrm{~m})$ (Kurter 1991). The largest occur on Mount Cilo $(4,135 \mathrm{~m})$ where the Uludoruk glacier is nearly $4 \mathrm{~km}$ long and covers an area of $8 \mathrm{~km}^{2}$. In common with many other glaciers in Turkey, it has retreated throughout the twentieth century and the altitude of the glacier front rose approximately $400 \mathrm{~m}$ between 1937 and 1991 (Çiner 2004).

Smaller glaciers occur in the central Taurus (Orta Toroslar), further to the west on the mountains of Alada $\breve{g}(3,756 \mathrm{~m})$ and Bolkardağ $(3,524 \mathrm{~m})$. The snowline in these areas is situated at $c .3,450 \mathrm{~m}$ and glacier survival in such marginal conditions is controlled by local climatological and physiographic conditions (Kurter 1991). In the Aladağ Massif, a small glacier covering an area of $<1 \mathrm{~km}^{2}$ is considered to be a glacier remnant consisting largely of dead ice buried by rock debris. A considerable thickness $(c .120 \mathrm{~m})$ of perennial snow, firn, and ice has been reported from this site in a deep karstic shaft at c.3,400 m (Bayari et al. 2003).

The northern slopes of the Pontic Mountains drain into the Black Sea and receive some of the highest precipitation levels in Turkey. In the east of this area, for example, mean annual precipitation exceeds 2,000 $\mathrm{mm}$ (Kurter 1991). As a result, the snowline on the northern slopes is between 3,100 and $3,400 \mathrm{~m}$ and this is considerably lower than on most other mountains in Turkey. At least twelve small glaciers exist in the Pontic Mountains and, together, they cover an area of about $2.54 \mathrm{~km}^{2}$ (Ciner 2004).

\section{The Balkans}

Modern glaciers are not present in Greece since the permanent snowline is situated well above most of the highest peaks. The snowline is above $3,000 \mathrm{~m}$ in the Pindus Mountains of northern Greece and above 3,500 m across Crete (Messerli 1980). Nevertheless, all these mountains experience heavy winter snowfalls and, on the highest peaks $(>2,500 \mathrm{~m})$ such as Mount Olympus $(2,912 \mathrm{~m})$, even summer snowfall is common (Sahsamanoglu 1989).

On the highest slopes of the Pindus Mountains periglacial features are very well developed and some appear to be active today. Thick accumulations of snow undergo cycles of freezing and thawing during the spring and summer melt. Patterned ground, solifluction, and related features occur in the zone above $1,800 \mathrm{~m}$ as far south as Crete, and have been attributed to presentday periglacial processes (Poser 1957). Periglacial activity is likely to be a significant geomorphological agent in the highest areas of the Greek mountains where mean monthly temperatures are well below $-5^{\circ} \mathrm{C}$ and mean minimum temperatures are between -20 and $-25^{\circ} \mathrm{C}$ during the coldest month (Furlan 1977: 195, 201). Lapse rate data indicate that the mean annual temperatures at $2,400 \mathrm{~m}$ are likely to be $<3^{\circ} \mathrm{C}$, so the highest areas of the Pindus Mountains can be considered 'true' periglacial environments, as defined by French (1996: 23).

Further north in the former Yugoslavian republics and in Albania, the climate is harsher and more continental than in Greece. An absolute minimum winter temperature of $-29.6^{\circ} \mathrm{C}$ has been observed at the summit of Bjelašnica $(2,067 \mathrm{~m})$ in central Bosnia and mean temperatures in January are below $-5^{\circ} \mathrm{C}$ over large areas of the mountainous Balkan interior (Furlan 1977). Snowfalls are heavy in most areas; with drifts locally exceeding several metres (Figure 12.2a) and snow can persist well into summer (Figure 12.2b). 

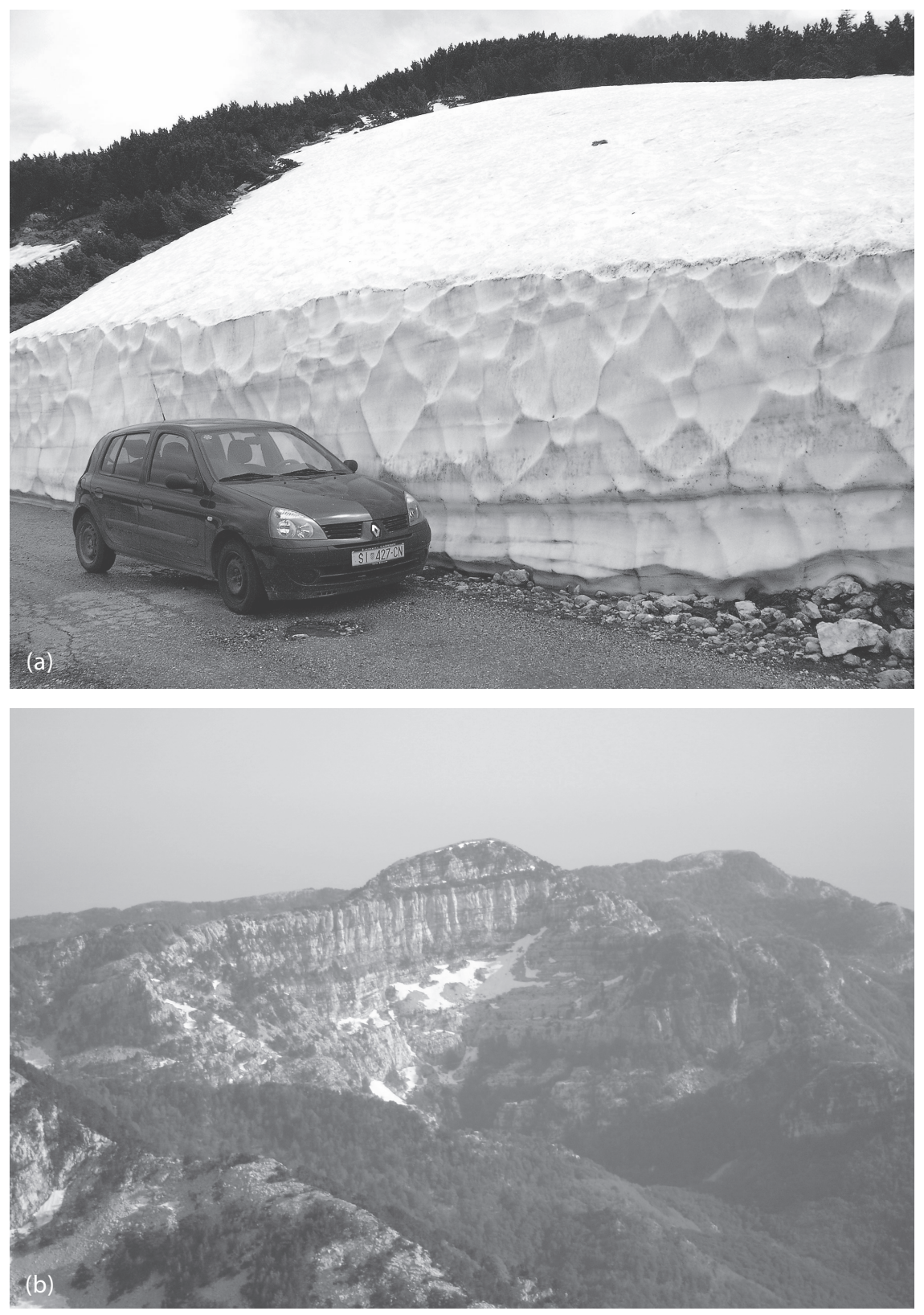

Fig. 12.2. (a) Snow accumulation to a depth of $c .3 \mathrm{~m}$ in early June at an altitude of $c .2,000 \mathrm{~m}$ a.s.l. between the villages of Zabljak and Crna Gora on the northern slopes of Durmitor (2,522 m a.s.l.), in Montenegro. (b) Looking west from the summit of Mount Orjen (1,894 $\mathrm{m}$ a.s.l.) towards the subsidiary summit of Subra (1,679 m a.s.l.), which is situated less than $15 \mathrm{~km}$ from the coast of Montenegro. In this area, annual precipitation values average over 5,000 $\mathrm{mm}$ - the highest in Europe-and snow patches persist into June down to altitudes as low as $1,000 \mathrm{~m}$ a.s.l. (photos: Philip Hughes). 


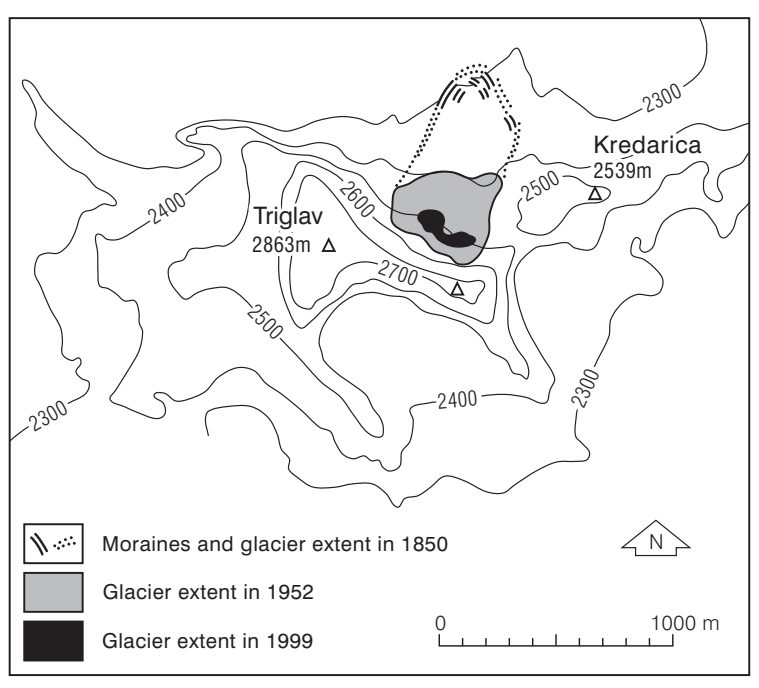

Fig. 12.3. Map of the Zeleni Sneg glacier on Mount Triglav, Slovenia, depicting ice retreat since the mid-nineteenth century. Based on sources cited in the text.

The coastal Dinaric Alps are the wettest part of Europe. Here, mean annual precipitation can exceed $5,000 \mathrm{~mm}$ and the absolute annual maximum of 8,063 mm was recorded in 1937 (Magaš 2002). Despite such high precipitation values, only a few glaciers exist in locally favourable topographic settings, since the snowline occurs at above the highest peaks of this area (Hughes 2007).

On Mount Triglav (2,864 m a.s.l.), in the Julian Alps of Slovenia, the Zeleni Sneg glacier is situated on the northern slopes between c.2,550 and $2,400 \mathrm{~m}$. Figure 12.3 illustrates the fluctuations in the size of this glacier over the last 150 years and highlights its dramatic retreat throughout the second half of the twentieth century (Sifrer 1963). By 1995 the glacier covered an area of only $0.0303 \mathrm{~km}^{2}$ (Gabrovec 1998). Increases in summer temperatures and maximum daily temperatures from May to September between 1954 and 1994 are closely correlated with the retreat of the glacier front and the reduction in ice thickness (Gams, 1994).

Small glaciers and permanent snowfields are present further south in the Dinaric Alps. A small glacier called Debeli Namet, is present on the north face of Sljeme (2,455 m a.s.l.) in the Durmitor Massif, Montenegro (Figure 12.4) (Hughes 2007). It is possible that this glacier represents the remnants of a Little Ice Age glacier, since the lower margins are bounded by arcuate subrounded boulder ridges and a distinct trimline marks the boundary between freshly scoured bedrock and older glaciated terrain (Figure 12.4). Small glaciers and permanent snowfields also occur in the Prokletije Mountains (2,694 $\mathrm{m}$ a.s.l.) on the border of Montenegro and Albania. Several glaciers were mapped in the First World War by the Ministry of Arms of the Austro-Hungarian Empire (Roth von Telegd 1923), although the current state of these features is unknown. If glacier ice is still present in the Prokletije, then these would represent some of the most southerly glaciers in Europe-at a similar latitude to the Calderone glacier in Italy discussed below.

\section{The Italian Appenines}

The Apennine Mountains span the length of the Italian Peninsula. The highest peak is Corno Grande $(2,912 \mathrm{~m}$ a.s.l.) in the Gran Sasso of Abruzzi where the Calderone glacier is found. This is Europe's southernmost glacier. The glacier occurs below the regional snowline in a steep-sided, north-facing cirque (Gellatly et al. 1994) where the local topography creates a microclimate suitable for glacier development. The glacier has retreated through the twentieth century and between 1916 and 1990 its volume is estimated to have been reduced by about 90 per cent and its area by about 68 per cent (ibid.). The future of the Calderone glacier is therefore in doubt and in common with other glaciers of southern Europe, it will soon disappear (J. M. Grove 2004: 218). Glaciers are not present anywhere else in the Italian Apennines. However, permanent ice has been reported in Sicily from the Grotta del Gelo (Cave of Frost) at c.2,030 m a.s.l. on Mount Etna (Marino 1992). The cave is situated well below the regional snowline and again the presence of ice is likely to be controlled by local conditions.

The lower limit of discontinuous permafrost is estimated to be at $c .2,600 \mathrm{~m}$ in the Apennines, based on rock glacier activity and the occurrence of perennial snow patches (Dramis and Kotarba 1994). Several active periglacial features have been described in the Gran Sasso Massif. These include patterned ground, stone-stripes, solifluction lobes, ploughing blocks, and nivation landforms reported above the treeline $(c .2,000 \mathrm{~m})$ by Gentileschi (1967a, b) and Kelletat (1969), and down to about 1,600 m by D'Alessandro et al. (2003). The lower zone is characterized by the seasonal occurrence of spring snow avalanches which can destroy any woodland in their path (D'Alessandro and Pecci 2001; D'Alessandro et al. 2003). This phenomenon was also witnessed by the authors in the Pindus Mountains in May 2003 (Figure 12.5). 


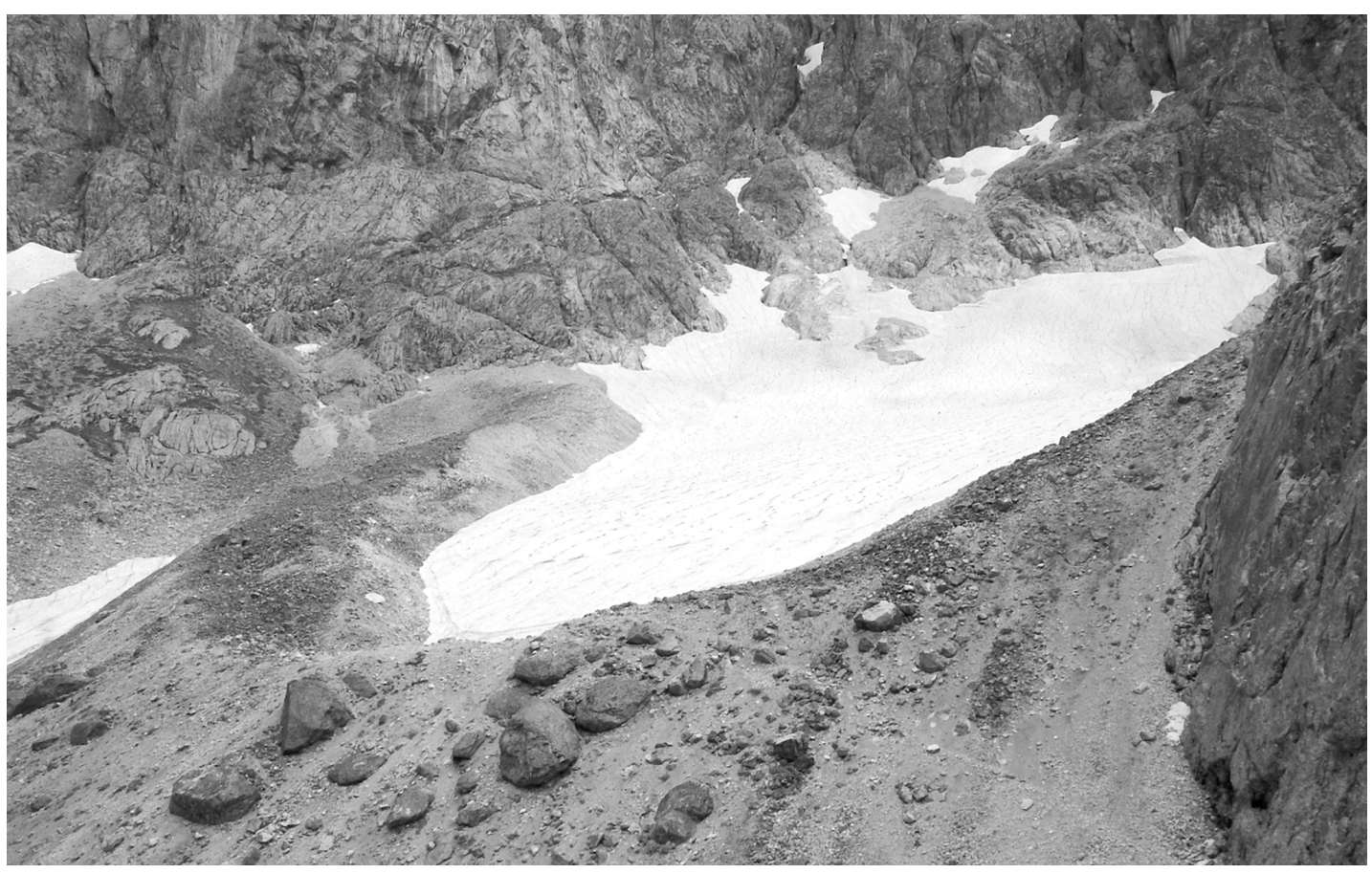

Fig. 12.4. The Debeli Namet glacier on the northern slopes of Sljeme (2,455 m a.s.I.) in Montenegro (photo: Philip Hughes).

\section{The Alpes Maritimes}

The Alpes Maritimes of southern France and western Italy currently support fifteen small glaciers (Federici and Pappalardo 1995). These glaciers are the southernmost of the Alpine chain and some are situated less than $50 \mathrm{~km}$ from the Mediterranean Côte d'Azur (Figure 12.1). Thirteen of the glaciers are found in the Argentera Massif, which contains the highest peaks of Alpes Maritimes. The ELA (equilibrium line altitude) of the six largest Argentera glaciers is currently c.2,800 $\mathrm{m}$ a.s.l. (Fisinger and Ribolini 2001). In common with other parts of the Mediterranean, all of these glaciers have retreated during the last century and recent glacier behaviour is probably a prelude to the extinction of the glacier ice in the Alpes Maritimes (Federici and Pappalardo 1995; Pappalardo 1999).

The lower boundary of discontinuous permafrost in the Argentera Massif occurs at c.2,500 to 2,600 m and active rock glaciers, blockfields, blockstreams, and gelifluction lobes are generally located above these altitudes (Fisinger and Ribolini 2001; Ribolini and Fabre 2006). On the Italian side of the Argentera Massif, seventy-one rock glaciers have been identified. However, most of these are likely to be relict features since some have front elevations as low as $2,350 \mathrm{~m}$-which is well below the present-day limit of discontinuous permafrost (Ribolini 1999; Fisinger and Ribolini 2001).

\section{The Pyrenees}

On thirteen peaks in the Pyrenees (Figure 12.6), all over $3,000 \mathrm{~m}$, Serrat (1993) identified forty-one glaciers that covered a total area of $8.10 \mathrm{~km}^{2}$ in 1984 . The largest glacier is the Glaciar d'Aneto in the Spanish Pyrenees, which covered an area of $1.32 \mathrm{~km}^{2}$ in 1984 . Glacier extent has declined since then and Chueca et al. (2005) reported that the Glaciar d'Aneto had retreated to cover an area of only $0.904 \mathrm{~km}^{2}$. The glaciers of the Pyrenees are situated close to threshold conditions for glaciation and their development and morphology are strongly influenced by the effects of topography on aspect and shadowing (Chueca and Julián 2004). Most glaciers have suffered negative mass balance in recent years and the Maladeta glacier had a mean specific net balance of $-811 \mathrm{~mm}$ and $-1,102 \mathrm{~mm}$ (water equivalent) in 2001/2 and 2002/3, respectively (World Glacier Monitoring Service 2003, 2005). The Pyrenees glaciers appear not to be in equilibrium with modern climate, and further rises in temperature are likely to raise the glacier threshold above the highest cirques. 


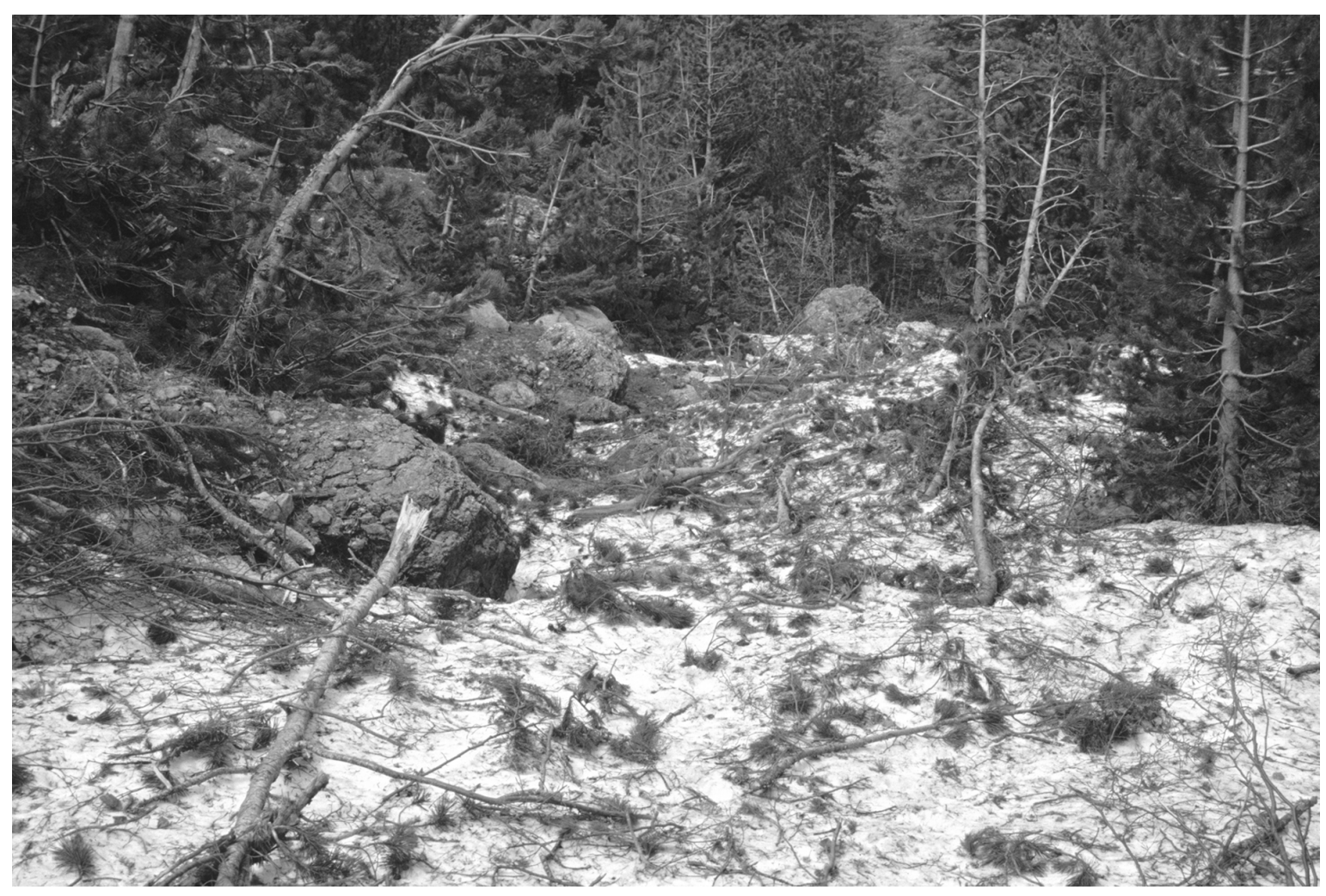

Fig. 12.5. The effects of snow avalanching on beech trees on the northern slopes of Mount Tymphi, Greece (photo: Jamie Woodward).

Serrano et al. (1999) identified thirteen active rock glaciers in the central Pyrenees, with five on the northern slopes and eight on the southern slopes. The south-facing rock glaciers had formed on peaks that exceeded $2,950 \mathrm{~m}$ and a lower limit of discontinuous permafrost was identified at c.2,800 $\mathrm{m}$ a.s.l. on the north-facing slopes. However, in common with the glaciers, conditions for permafrost are becoming increasingly marginal in the high mountains of the Mediterranean. This was highlighted for this region by Chueca and Julián (2005) who undertook a ten-year geodetic survey of the Besiberris rock glacier in the central Pyrenees. They found a marked thinning of a central ice core that they attributed as a response to recent climatic amelioration.

\section{Iberia}

On the Iberian Peninsula south of the Pyrenees, few glaciers occur today and there is some debate as to whether any exist at all. González-Suárez and Alonso (1994) reported the presence of a small glacier in the
Picos de Europa $(2,651 \mathrm{~m})$, the highest Massif of the Cantabrian Mountains, and attributed its existence to high precipitation and shading. However, Frochoso and Castañón (1995) argued that these features represent fossil ice bodies inherited from the LIA and that today, only perennial snow patches and sporadic permafrost occur in this area.

On many of the highest Iberian peaks, snow persists for more than 220 days of the year. Snow accumulation is an important influence on present-day geomorphological and biogeographical processes-especially on northern and eastern slopes (Palacios et al. 2003). In the Peñalara Massif $(2,428 \mathrm{~m}$ a.s.l.) of central Spain, for example, nivation niches, protalus ridges, and nivoalluvial fans are actively forming today.

In southern Spain, glacier ice existed until the late twentieth century in the Sierra Nevada at the foot of the north wall of Picacho del Veleta $(3,398 \mathrm{~m})$ in the Corral Veleta cirque (García 1996). Drilling investigations have shown that ice still exists within the talus in this cirque down to $c .3,050$ to 3,100 m (Gómez et al. 2001, 2003). The buried ice in the Corral del Veleta is 


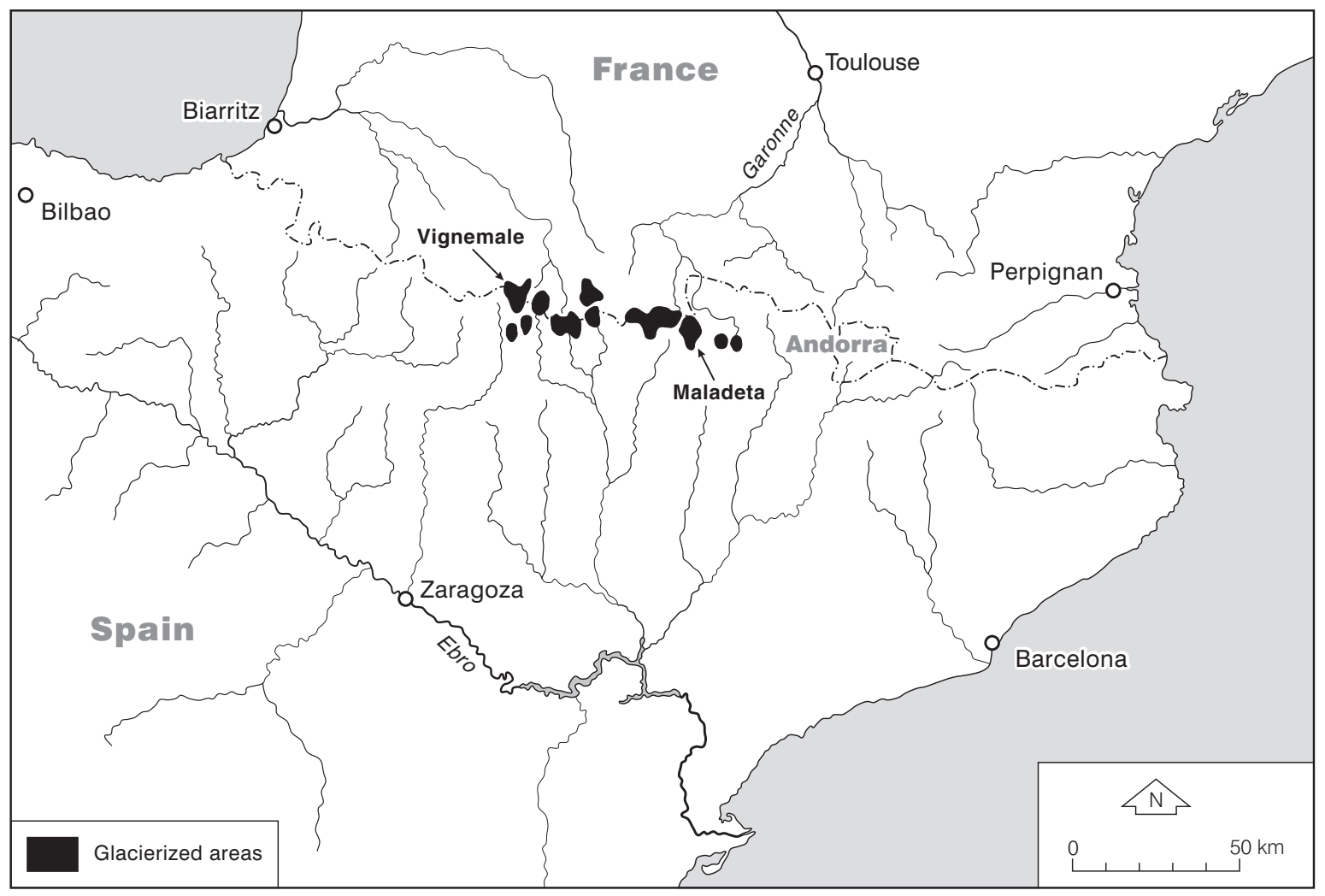

Fig. 12.6. The distribution of currently glacierized areas in the Pyrenees. All the glaciers are small cirque glaciers and the shaded areas represent general glacierized areas and not the glaciers themselves. Based on sources cited in the text.

significant because it represents the southernmost permafrost remnant in Europe (Gómez et al. 2001) and periglacial processes are likely to be active in other areas of the Sierra Nevada. In fact, the whole summit area of the Sierra Nevada, which culminates at the peak of Mulhacen $(3,478 \mathrm{~m})$, represents a marginal area of discontinuous permafrost (Gómez et al. 1999) characterized by miniature patterned ground, terracettes, and active solifluction lobes (Simon et al. 1994; Gómez-Órtiz and Salvador Franch 1998).

In the Serra da Estrela of Portugal (Figure 12.1), Brosche (1978) and Daveau (1978) have reported the occurrence of a periglacial belt on the highest slopes, but they present conflicting opinions of its extent. However, Vieira et al. (2003) have argued that periglacial activity related to permafrost processes, sensu stricto French (1996), is not present in the Serra da Estrela, but recognize that frost action and associated cryogenic landforms are active. These include miniature sorted stripes and nets, microforms related to needle- ice activity, incipient solifluction lobes, terracettes, signs of microgelivation, and evidence of upfreezing of granules (Vieira et al. 2003). Here, as in many other Mediterranean mountain areas, it would appear that, whilst permafrost is absent, cryogenic processes play an active role in sediment production and landform development.

\section{The Atlas Mountains}

The Atlas Mountains are the most southerly mountains in the Mediterranean basin and extend over $1,000 \mathrm{~km}$ from Morocco to Tunisia. The highest mountains occur in the High Atlas in Morocco where Mount Toubkal reaches $4,165 \mathrm{~m}$. Further north in the Middle Atlas the highest peak of Jbel Bou Iblane reaches 3,340 m. Elsewhere, in the Rif, Tell, and Saharan Atlas ranges, peaks do not exceed $2,500 \mathrm{~m}$. Periglacial features such as solifluction lobes, rasentrappen (German: 'sea of rock'; a mantle of angular shattered boulders), 


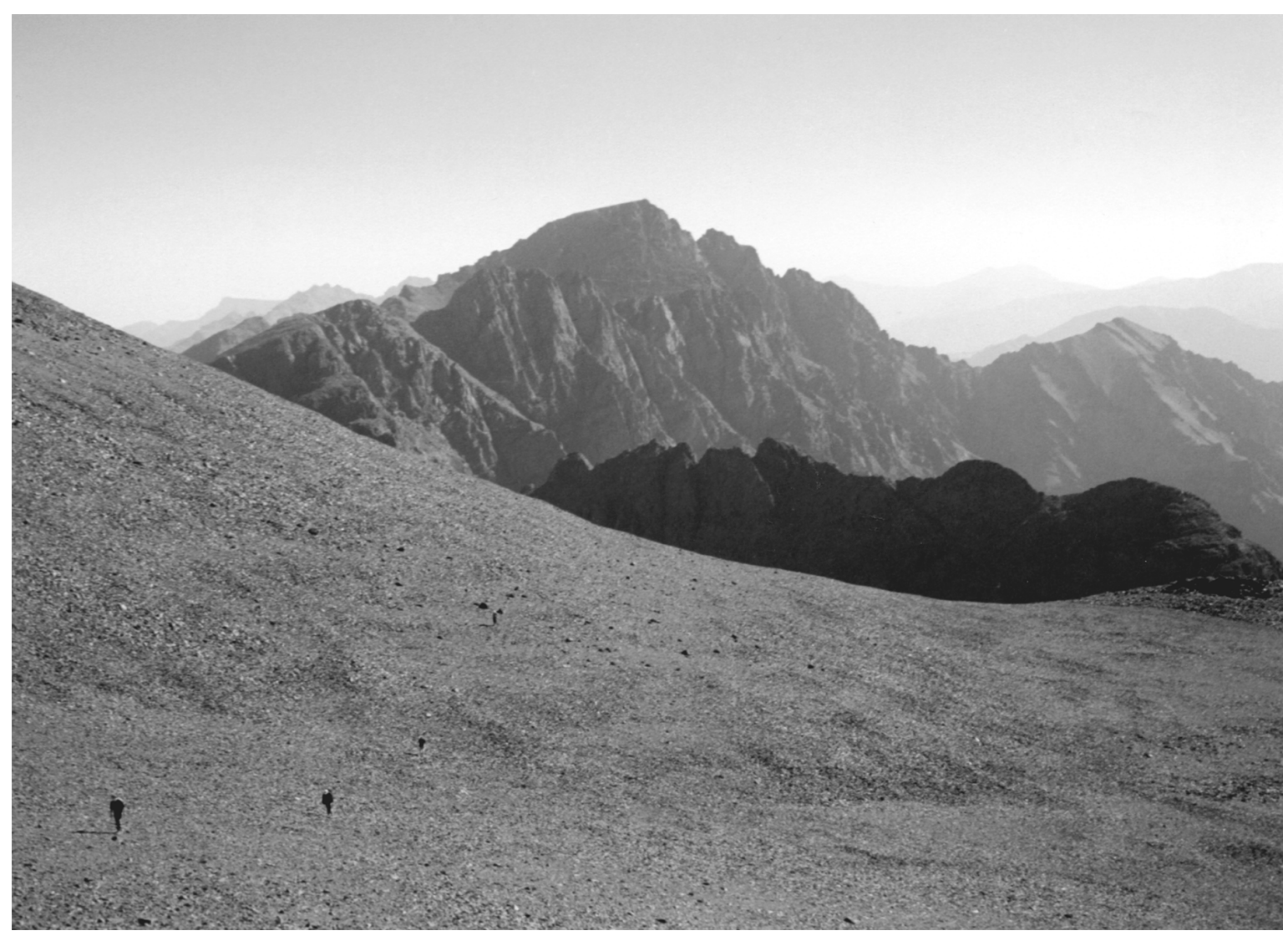

Fig. 12.7. An unglaciated periglacial surface covered in felsenmeer (blockfield) on Ouanoukrim (4,063 m a.s.l.) in the Atlas Mountains. Glacier ice occupied the cirque in silhouette in the middle distance. Mount Toubkal (4,165 m a.s.l.), the highest peak in the Atlas Mountains, is in the background (photo: Philip Hughes).

thufurs (mounds formed by heaving of the ground surface), polygons, stone stripes, and felsenmeer are active today above 2,000 $\mathrm{m}$ in the High Atlas (Couvreur 1966) (Figure 12.7). Frosts are frequent and winter temperatures can fall below $-20^{\circ} \mathrm{C}$ with snow lingering until early summer on the highest peaks (Robinson and Williams 1992). At one site below the northern cliffs of the Tazaghart plateau, in the Toubkal area, perennial snow has been reported by Smith (2004).

\section{Holocene and Little Ice Age Glacial and Periglacial Environments}

Climate during the Holocene (the last 11,500 years) has been relatively stable compared to the rapid and pronounced shifts in temperature that took place during the Last Glacial stage (cf. Dansgaard et al. 1993;
Chapter 4). However, the Holocene has been characterized by climatic oscillations of sufficient magnitude to cause significant glacier oscillations in various parts of the world including the Mediterranean region. The most recent major glacier advance, recorded in most mountain ranges across the world, occurred during the LIA. The term 'Little Ice Age' is widely used to describe a period of glacial advance between c.1550 and 1800 (Lamb 1977: 104) and was characterized by global cooling of the order of $1-2^{\circ} \mathrm{C}$ (J. M. Grove 2004: 591). Glaciers advanced in most glaciated European mountain regions, such as in Iceland, Scandinavia, and the Alps. Glacier advances in the Alps have been linked with extreme weather types in the Mediterranean region during the LIA, including extreme rainfall, heavy snow, and intense cold (A. T. Grove 2001). The impacts on flooding and river basin processes are discussed in Chapter 11. Glaciers are known to have advanced in 
the Pyrenees, Alpes Maritimes, Italian Apennines, and in Turkey during this period. In some areas, such as southern Spain, glaciers that were present during the LIA no longer exist.

\section{Turkey}

In the Turkish mountains, glaciers appear to have begun retreating in the early twentieth century, a process that has accelerated since the 1930s (Erinç 1952; Güner and Emre 1983; Çiner 2004). However, detailed knowledge of the Holocene history of most Turkish mountain glaciers is not yet available.

\section{The Balkan Peninsula}

In the Balkans, historical documents record severe cold and heavy snowfalls during the LIA, especially during 1676-1715 and 1780-1830 (Xoplaki et al. 2001). In the winter of $1686 / 7$, almost every region of Greece experienced severe cold and heavy snow and Lake Pamvotis at Ioannina remained frozen for more than three months (Chapter 4). The winter of $1708 / 9$ was also particularly severe in the Balkans and is widely regarded as one of the most severe of the last 500 years, resulting in widespread famine, plague, and death in the former Yugoslavia (Xoplaki et al. 2001). Few studies, however, present evidence for the effects of climatic deterioration during the LIA on glacial and periglacial landform development in the mountains of the Balkans. An exception is at the Zeleni Sneg glacier on Triglav in the Julian Alps, Slovenia. This glacier covered an area of $c .40$ hectares in the nineteenth century (Sifrer 1963) but, as noted earlier, had retreated to only a few hectares by 1995 (Gabrovec 1998) (Figure 12.3).

\section{The Italian Apennines}

The Calderone glacier, in the central Apennines, was much more extensive during the LIA compared with today. Moraines at the threshold of the Calderone cirque have been attributed to the LIA and occur 1,000 to $1,050 \mathrm{~m}$ above moraines attributed to the Würmian glacial maximum (Federici 1979; Gellatly et al. 1994). More recently, Giraudi (2003, 2004) recognized a complex of Holocene Neoglacial glacial units in this area and identified five phases of glacier advance, using radiocarbon dating to establish the age of interbedded soils. Giraudi (2004) proposed that ice had completely melted in the Calderone cirque by $9,000^{14} \mathrm{C}$ years BP and subsequent glacier formation and expansion occurred after $3,890 \pm 60,2,650 \pm 60,1450 \pm 40$, and $670 \pm$ $40^{14} \mathrm{C}$ years вр. A final glacial advance during the fourteenth century AD covered these earlier units and formed the Neoglacial glacier maximum, thus mirroring glacier expansion elsewhere in Europe during the Little Ice Age (Giraudi 2003, 2004).

Variations in Holocene glacial activity and periglacial processes in the Apennines show that winter temperatures were $3.0^{\circ} \mathrm{C}$ lower than today between $c .790$ to 150 calendar years BP and $1.2^{\circ} \mathrm{C}$ higher than today between c.5,740 and 5,590 calendar years BP (Giraudi 2005).

\section{The Alpes Maritimes}

Federici and Stefanini (2001) carried out a lichenometric study on glacial deposits in the high mountains of the Alpes Maritimes to examine the nature of LIA glacier fluctuations. The most extensive glaciers of historical times occurred between the thirteenth and fourteenth centuries (c.AD 1215-50 and AD 1310-50) and moraines were deposited at higher elevations between c.AD 1640-90, 1760-1785, and 1825. All the glacier advances occurred during the LIA and the first correlates with glacier expansion elsewhere in the Alps ( $c f . \mathrm{J}$. M. Grove 2004). The mean ELA of the most extensive LIA glaciers in the Argentera area was c.2,650-2,700 m (Fisinger and Ribolini 2001). Earlier Holocene glacier advances are recorded by moraines at slightly lower altitudes and were formed by glaciers with a mean ELA of c. $2,600-2,650 \mathrm{~m}$.

\section{The Pyrenees}

The Pyrenees represent a classic area where glaciers are known to have advanced during the LIA and, in common with the Alps, glacier fluctuations were documented by observers as early as the eighteenth century. In the Hautes-Pyrenees, radiocarbon dating of sediments from a bog at c.2,100 $\mathrm{m}$ in the Cirque de Troumouse showed that moraines immediately downvalley formed during the Holocene before $c .51900^{14} \mathrm{C}$ years BP (Gellatly et al. 1992). Neoglacial events are also indicated by younger silt-rich sediments in the bog and two younger moraine sets on the cirque floor at altitudes of $c .2,250$ to 2,350 m. Little Ice Age glaciers were more restricted in extent, and are recorded by moraines at c.2,360 and at c. 2,650 m, close to the cirque wall (Gellatly et al. 1992).

Observations of LIA glacier characteristics were made by Louis-François Ramond de Carbonnières in the late eighteenth century-when glaciers were significantly more extensive than today (Grove and Gellatly 1995; J. M. Grove 2004) (Figures 12.8 and 12.9). Glacier retreat during the early nineteenth century was followed by a mid-nineteenth-century readvance, albeit smaller than the late eighteenth century readvance. This was followed by a period of major glacier contraction 


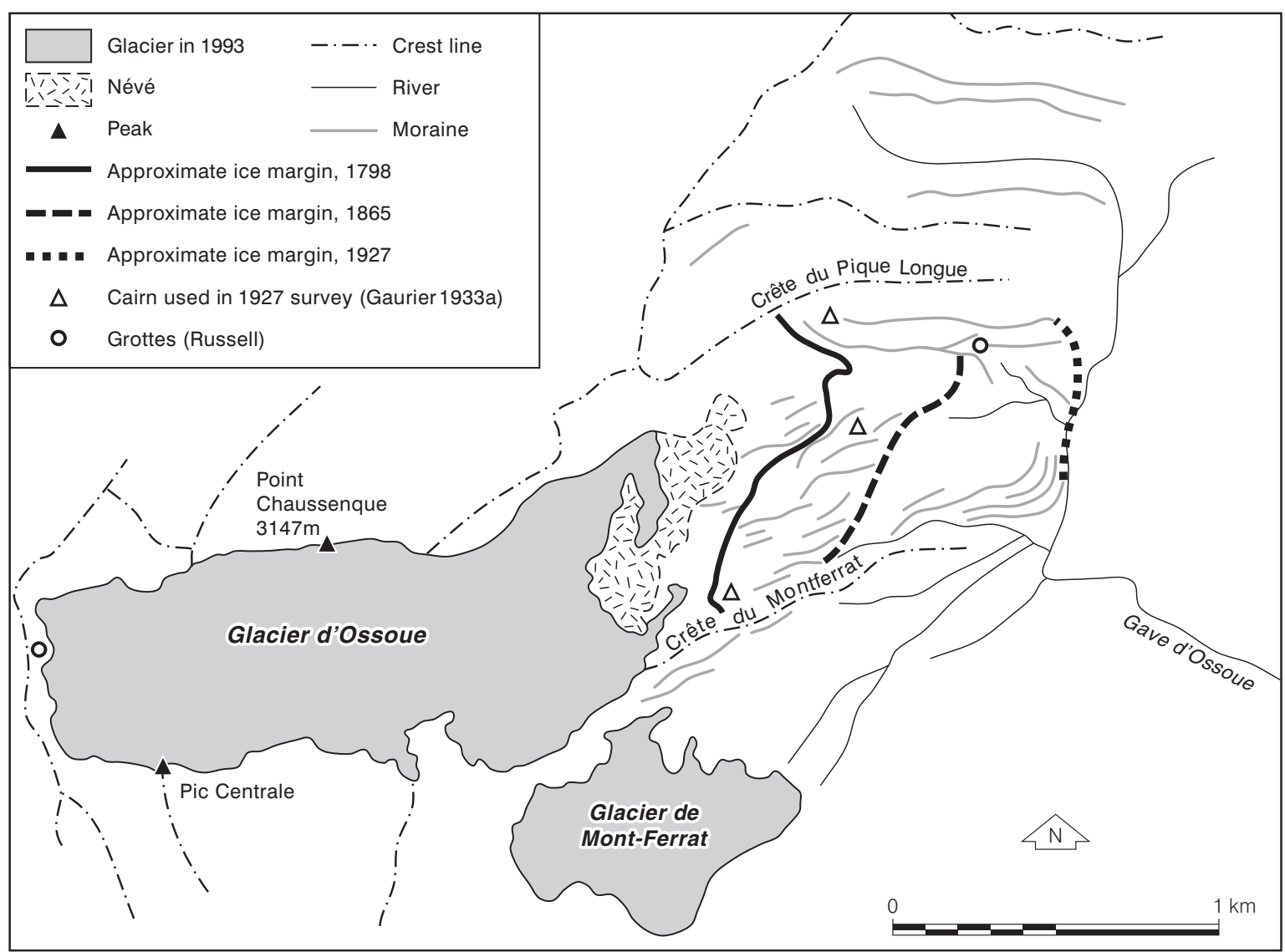

Fig. 12.8. Map of the Glacier d'Ossoue, the largest modern glacier in the Pyrenees, showing former ice margins in 1798, 1865, 1927, and 1993 (modified from an original sketch map compiled from aerial photographs and field mapping in Grove and Gellatly 1995).

between 1864 and 1870 (Michelier 1887). At Glacier du Pays Baché- on the eastern side of the Néouville Massif in the Hautes-Pyrenees-Michelier estimated that the glacier lost $c .8,400,000 \mathrm{~m}^{3}$ in volume as a result of reduced precipitation and warmer winters after the middle of the century until the 1880 s. The late nineteenth century was characterized by yet another advance and Bonaparte (1890) presented photographic evidence of increased ice thickness between 1880 and 1890. J. M. Grove (2004: 199), too, cites evidence for increased accumulation for the period 1885-95 at Glacier d'Ossoue on Vignemale (Figure 12.8). Whilst glacier recession has dominated the twentieth century, it has not been continuous, as glaciers either stabilized or advanced slightly during the intervals from 190611, 1926-7, 1944-5, 1963-4, and 1978-9 (Grove and Gellatly 1995; J. M. Grove 2004).

In the Posets Massif of Spain, the second highest in the Pyrenees, Serrano et al. (2002) identified six phases of LIA glacier behaviour with the maximum extension of glaciers reached between 1600 and 1750. A minor advance occurred between 1905 and 1920, whilst the interval 1920-80 was generally characterized by glacier recession and a particularly rapid recession between 1980 and 2000 (Serrano et al. 2002). Overall, the total reduction in glacier surface area since the LIA is estimated at 39.2 per cent in the Posets Massif (Chueca et al. 2005).

Figure 12.9 shows the extent of LIA glacial deposits presented in J. M. Grove (2004: 190) on the Maladeta Massif, the highest Massif of the Pyrenees, and to the east of the Posets Massif. A recent study by Chueca et al. (2005) reconstructed the LIA evolution of the Maladeta glacier; the largest in this area. This glacier reduced in size by 35.7 per cent from 152.3 hectares in 1820-30 to 54.5 hectares in 2000 and the ELA rose by $255 \mathrm{~m}$ over the same period. However, glacier retreat was interrupted by at least three phases of 


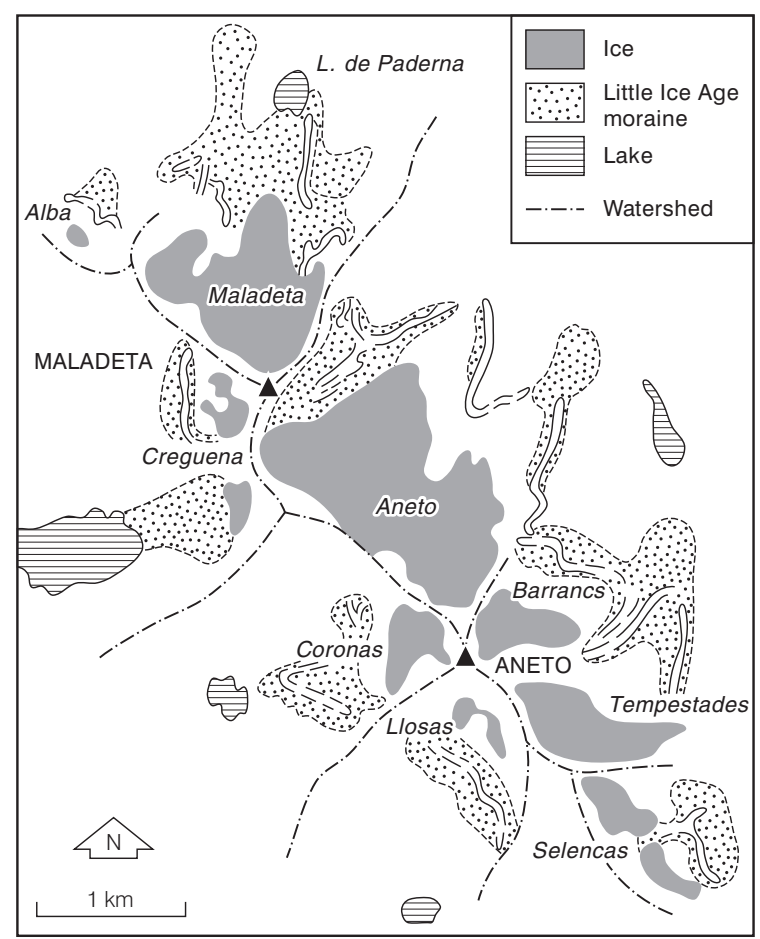

Fig. 12.9. Map of the glaciers of the Maladeta Massif where some of the largest modern glaciers in the Pyrenees are found (modified from J. M. Grove 2004: 190).

significant stability during the intervals 1820-30 to 1857; 1914-20 to 1934-5; and 1957-81. Ice depletion here was matched by ice loss across the Pyrenees and the rising ELA is characteristic of trends observed in other Mediterranean glaciers.

\section{Iberia}

The Corral Veleta glacier in the Sierra Nevada is the most celebrated LIA glacier in the Mediterranean (Messerli 1967; García 1996). This glacier reached $800 \mathrm{~m}$ in length during the LIA, but never advanced beyond the confines of its cirque and began its retreat in the mid1800s. Further north, on the northern slopes of Pico Almanzor (2,592 m), in the Sierra de Gredos of central Spain, Sancho et al. (2001) used lichenometry to show that a protalus rampart, situated at the base of a nivation patch, formed during the LIA. This evidence supports other studies that suggest that there was a substantial increase in snow cover in the Sierra de Gredos during the LIA (e.g. Toro et al. 1993).

\section{Pleistocene Glacial and Periglacial Environments}

As Figure 12.10 shows, many Mediterranean mountains were glaciated during the Pleistocene (Messerli 1967; Hughes et al. 2006a; Hughes and Woodward, 2008). In some areas, this was restricted to the highest cirques, whilst in others ice fields formed and valley glaciers extended many kilometres into lowland areas. Significantly, the periglacial zone was lowered considerably during Pleistocene cold stages and, in conjunction with glacial and fluvial processes, it helped to shape much of the upland Mediterranean landscape we see today. Many Mediterranean mountain landscapes can therefore be viewed as products of Pleistocene glaciation and periglacial activity in addition to the influence of tectonic, fluvial, and associated processes. In several areas, glacial and periglacial processes have interacted with karstic processes to form some of the best examples of glacio-karst landscapes (Chapter 10). Notable examples occur in the Pindus Mountains, Greece (Waltham 1978; Woodward et al. 2004; Hughes et al. 2006b) and in the Picos de Europa of north-west Spain (Smart 1986).

\section{Turkey and the Near East}

In the Near East, evidence of former glaciation was first noted in the late nineteenth century by Diener (1886) in the mountains of Lebanon. According to Messerli (1967), glacial evidence is particularly well preserved on Qornetes Saouda $(3,088 \mathrm{~m})$, the highest peak of the Jbel Liban, and on Mount Hermon $(2,814$ m) in the southern Anti-Lebanon.

Further north in Turkey, evidence of Pleistocene glaciation can be found throughout the main mountain ranges. On Mount Ararat, in the eastern Taurus Mountains, the snowline was depressed to $c .3,000 \mathrm{~m}$ a.s.l. during the Pleistocene and the volcanic cone was covered by an ice cap of about $100 \mathrm{~km}^{2}$ (Blumenthal 1958). Wright (1962) estimated that Pleistocene snowlines across this part of Turkey were depressed by between 1,200 to $1,800 \mathrm{~m}$ and suggested that much of this depression can be attributed to increased snowfall (relative to today), in addition to lower summer temperatures.

The Taurus and Pontic mountains of Turkey were extensively glaciated during the Pleistocene. U-shaped valleys, moraines, roches moutonnées, and glacial lakes are abundant throughout this region (Çiner et al. 1999; Çiner 2004; Akçar and Schlüchter 2005). In the Aladag Massif of the central Taurus, an ice cap on the 


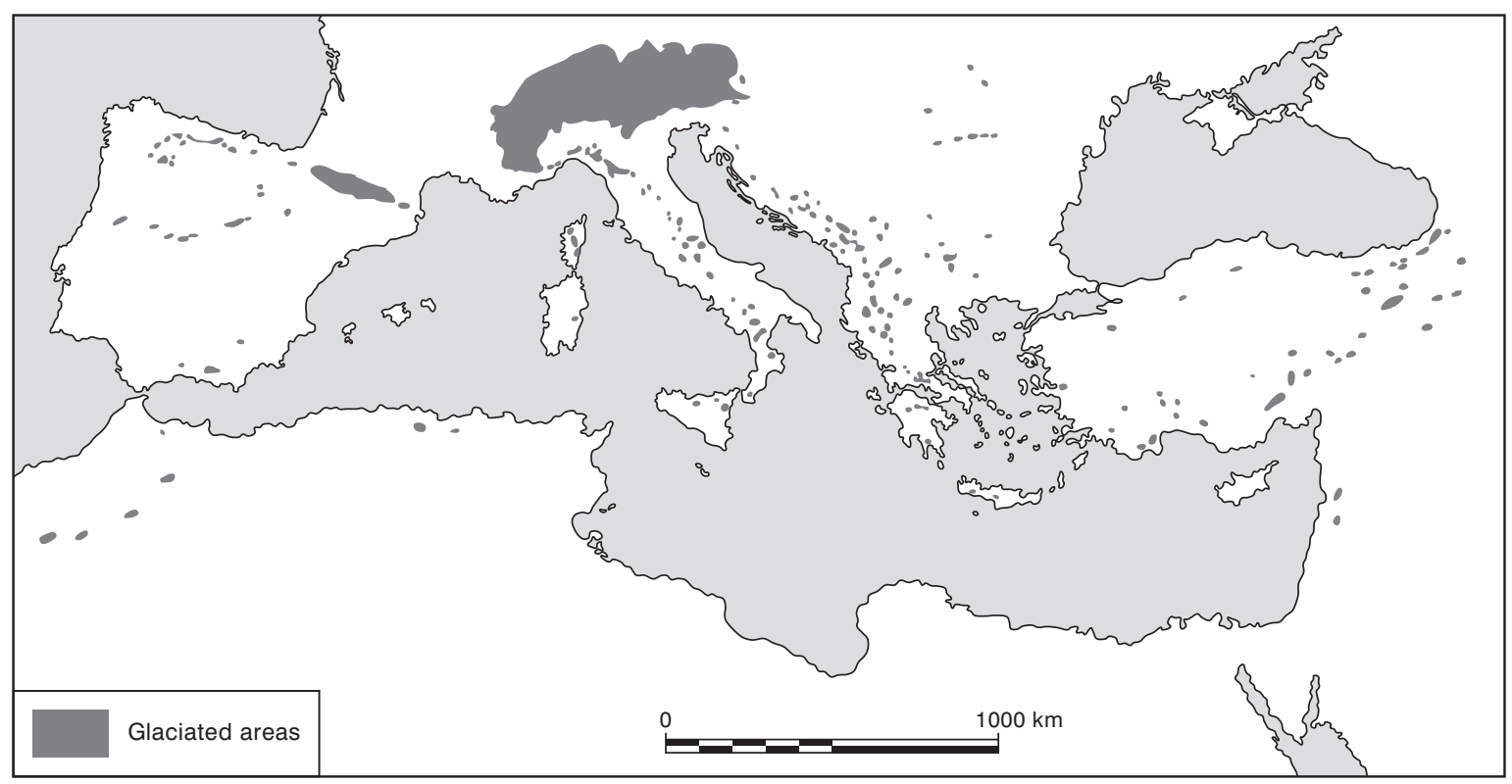

Fig. 12.10. Map of the former extent of Pleistocene glacial and nivation features in the Mediterranean (after Messerli 1967).

Yedigöller plateau (c.3,200 m a.s.l.) covered $40 \mathrm{~km}^{2}$ and outlet glaciers flowed into valleys to the north-east, west, and east (Bayari et al. 2003). Here there is evidence of seven episodes of glacial advance and retreat, although just two separate suites of moraines have been identified based on contrasting moraine 'freshness', with the best preserved above $1,800 \mathrm{~m}$, and others extending down to $1,200 \mathrm{~m}$ (ibid.). Relict rock glaciers have also been widely preserved and in the central Taurus two generations of rock glaciers are concentrated between 2,050 and 2,500 m a.s.l. (Arpat and Özgül 1972).

A very recent development in Turkey has seen the application of cosmogenic exposure dating to Pleistocene glacial records in the Kaçkar Mountains (Akçar et al. 2007, 2008) and in the western Taurus Mountains (Sarkkaya et al. 2008). These studies are providing important new insights into long-term glacier behaviour in the eastern Mediterranean and they have raised important new questions about the palaeoclimatic conditions associated with glacier development in this region (Hughes and Woodward 2008).

\section{The Balkans}

Glaciers formed in the mountains of Greece, Albania, and the former Yugoslavian states on multiple occasions during the Pleistocene (Hughes et al. 2006a).
In Greece, glacial deposits and landforms have been recorded by numerous workers (Niculescu 1915; Sestini 1933; Mistardis 1952; Messerli 1967; Pechoux 1970; Fabre and Maire 1983; Palmentola et al. 1990; Boenzi et al. 1992; Smith et al. 1997), and in many areas moraines and limestone pavements are very well preserved (Figures 12.11 and 12.12).

However, the timing of glaciation in Greece has only recently been established. On Mount Tymphi, in the northern Pindus, Woodward et al. (2004) dated calcite cements in tills using U-series methods and found that the oldest, most extensive glacial deposits were older than 350,000 cal. years BP (Figure 12.13). Subsequent work by Hughes et al. (2006b) has identified evidence for three glacial phases on Mount Tymphi by combining detailed geomorphological mapping with an extended programme of U-series dating.

Hughes et al. (2006b) correlated the various glacial and periglacial units recorded on Mount Tymphi with cold stage intervals recorded in the pollen stratigraphy from Ioannina about $40 \mathrm{~km}$ to the south (Tzedakis 1994; Tzedakis et al. 2002; Chapter 4). The Ioannina sequence was then used as a parastratotype to define a glacial chronostratigraphy for the Pindus Mountains and to facilitate correlations with the marine isotope record (Table 12.2). The extent of the former glaciers during the different glacial stages on Mount Tymphi is illustrated in Figure 12.15. A key outcome of this work is 


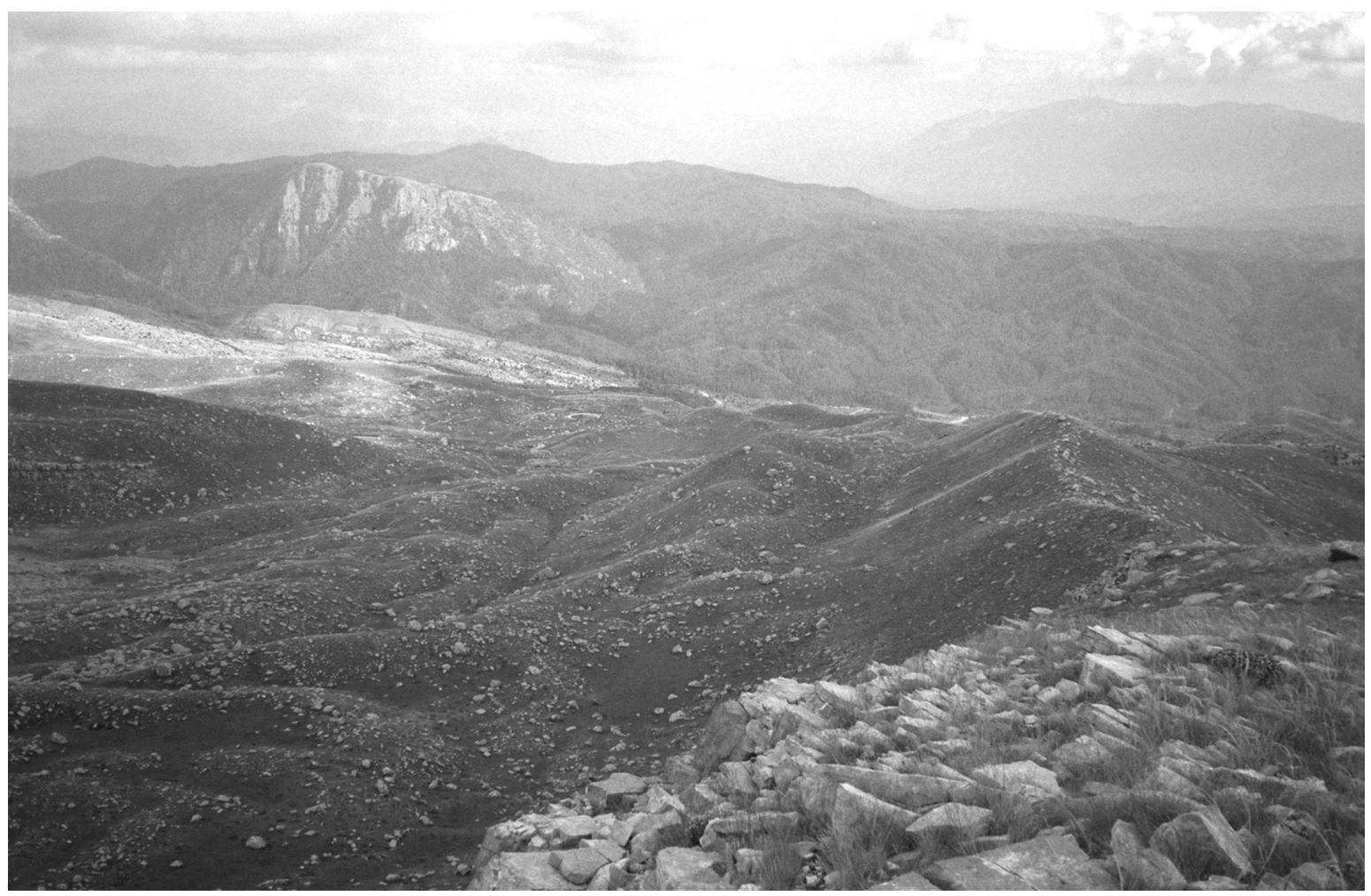

Fig. 12.11. Moraines at c.1,700 m a.s.l. in the Vourtapa valley above the village of Skamnelli on Mount Tymphi, Greece (photo: Philip Hughes).

that the glaciers of the last cold stage in Greece were much smaller than during earlier Middle Pleistocene glaciations.

Well-developed periglacial forms are often present inside former Pleistocene glacier limits. For example, thick accumulations of talus (Figure 12.14) inside of the Vlasian Stage (MIS 6) glacier limits (Figure 12.15, Table 12.2), are the product of periglacial weathering during the last cold (Tymphian) stage and, to a lesser extent, through the Holocene. Hughes et al. (2006c) found evidence of a similar glacial sequence to Mount Tymphi on neighbouring Mount Smolikas (2,637 m). Here, however, there is also evidence in the highest cirques for a fourth and later glacial phase when small cirque glaciers developed. These small glaciers on Smolikas had an ELA of c.2,420 m and covered a total area of $<0.5 \mathrm{~km}^{2}$. This phase of glaciation is likely to have occurred after the glacial maximum of the Tymphian Stage (Table 12.2) and possibly during the Younger Dryas (11,000-10,000 ${ }^{14} \mathrm{C}$ years BP) (ibid.).
The glacial history of Mount Olympus (2,917 m a.s.l.), the highest mountain in Greece, has been documented by Smith et al. (1997). The Olympus glaciers extended to the piedmont zone during the most extensive glacial phase down to altitudes as low as $500 \mathrm{~m}$ a.s.l. (Figure 12.16). Smith et al. (1997) proposed a tentative chronology for glaciation on Mount Olympus by correlating soils on glacial deposits with dated soils in the river deposits of the Larissa basin. The oldest and most extensive glaciation was correlated with soils older than 200,000 cal. years BP, leading Smith et al. (1997) to suggest that this glaciation occurred during MIS 8. A second phase of glaciation, characterized by upland ice and valley glaciers that did not reach the piedmont, was correlated with MIS 6. During the last major glacial phase, glaciers were restricted to valley heads, and this glacial phase was correlated with MIS 4 to 2. Smith et al. (1997) suggested that a further set of moraines at $c .2,200 \mathrm{~m}$ in the high cirque of Megali Kazania may be Holocene Neoglacial features. However, (Hughes et al. 2006c) have argued that features at a similar altitude on Mount 


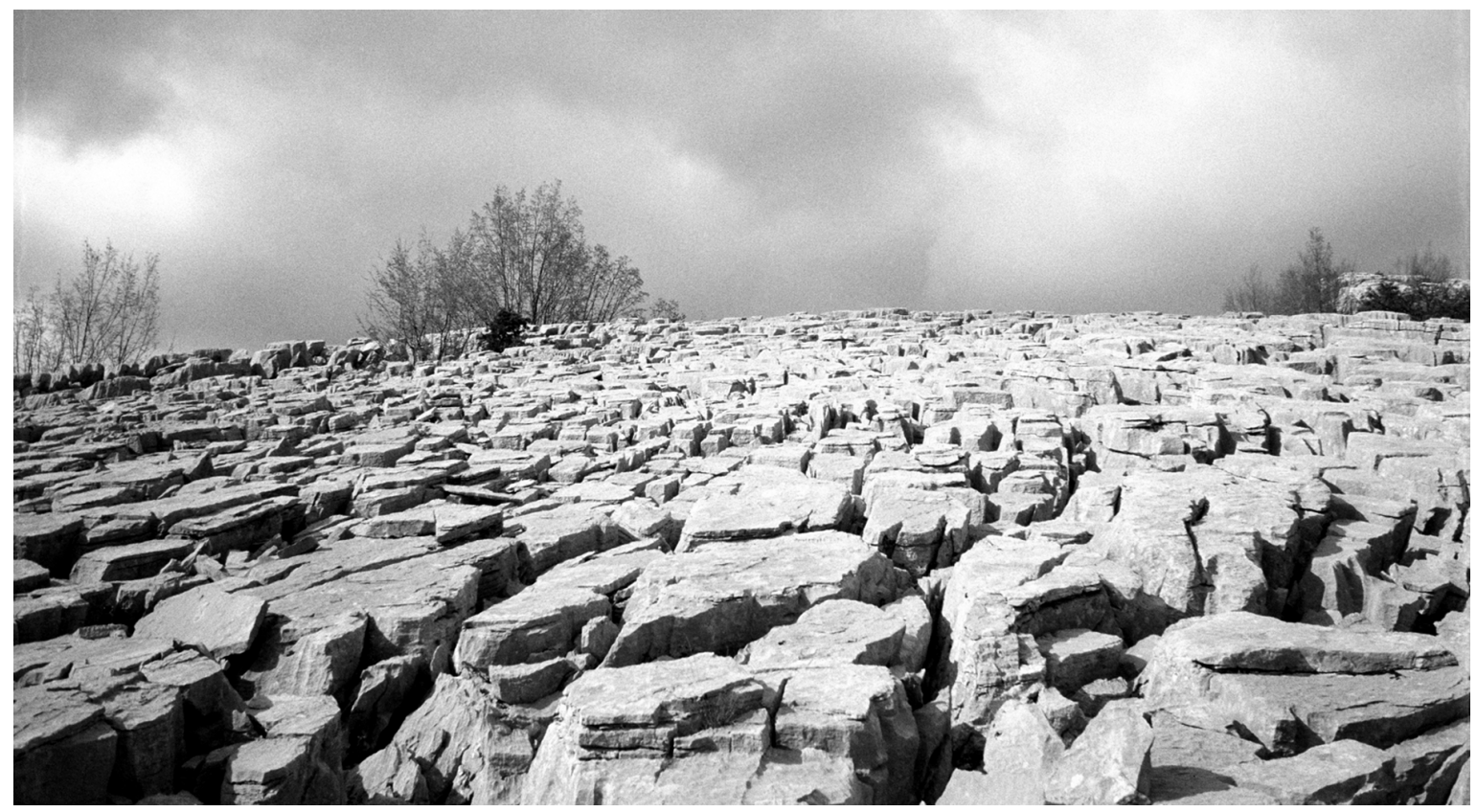

Fig. 12.12. Limestone pavement on Mount Tymphi, Greece (photo: Philip Hughes).

Smolikas (2,632 m a.s.l.) in the Pindus Mountains were Late Glacial in age.

The chronological model suggested for Olympus by Smith et al. (1997) differs from that established for the Pindus Mountains to the west. However, the morphostratigraphical sequences are very similar and, given the short distance between these areas, it is likely that the Olympus and Pindus sequences correlate. The dating framework proposed by Woodward et al. (2004) and Hughes et al. (2006b) for Mount Tymphi is likely therefore to provide a good approximation for the age of the glacial sequences on Mount Olympus, but this can only be confirmed by further work.

Almagià (1918) provided one of the earliest accounts of the evidence of former glaciation in the mountains of central and northern Albania. The largest glaciers formed in the Prokletije Mountains of northern Albania and early work by Roth von Telegd (1923) estimated that Pleistocene valley glaciers extended for some $35 \mathrm{~km}$ over the border into Montenegro near the towns of Gusinje and Plav. In fact, the town of Plav is built on moraines that dam a large lake at $c .900 \mathrm{~m}$ a.s.l. and the age of these moraines is currently the focus of research by the authors. In southern Albania, evidence for glaciation was reported by Louis (1926) from the mountains of Nëmerçka $(2,495 \mathrm{~m})$, on the
Epirus border, and Mali i Lunxheriës $(2,200 \mathrm{~m})$, south-west of Gjirokastër. More recently, Palmentola et al. (1995) have reported the presence of relict rock glaciers above $1,700 \mathrm{~m}$ that were set within more extensive glacial features in the Prokletije Mountains. The geochronology of glaciation in this area is yet to be established.

In the former republics of Yugoslavia, Jovan Cvijić was a pioneer of glacial research and produced remarkably detailed analyses of the glacial history of the region (e.g. Cvijic 1900, 1917). More recently, Menkovic et al. (2004) have compiled evidence of glaciation in the mountains of Serbia, Macedonia, and Montenegro. Glacio-karst landscapes dominate many of the highest uplands and glacial landforms are often well preserved (Figures 12.17 and 12.18). Some of the largest Pleistocene glaciers formed in the Prokletije Mountains, where glaciers extended over $35 \mathrm{~km}$, forming U-shaped valleys, moraines, and numerous glacial lakes (Cvijić 1913). Further west, on Mount Durmitor (2,523 m a.s.l.), in Montenegro, Alpine-type valley glaciers descended from the highest peaks into a large plateau ice field above canyons incised by the Piva and Tara rivers (Marovic and Markovic 1972; Nicod 1968; Menkovic et al. 2004). A major ice cap also formed on Maganik to the south and, here, the glacial limits on 


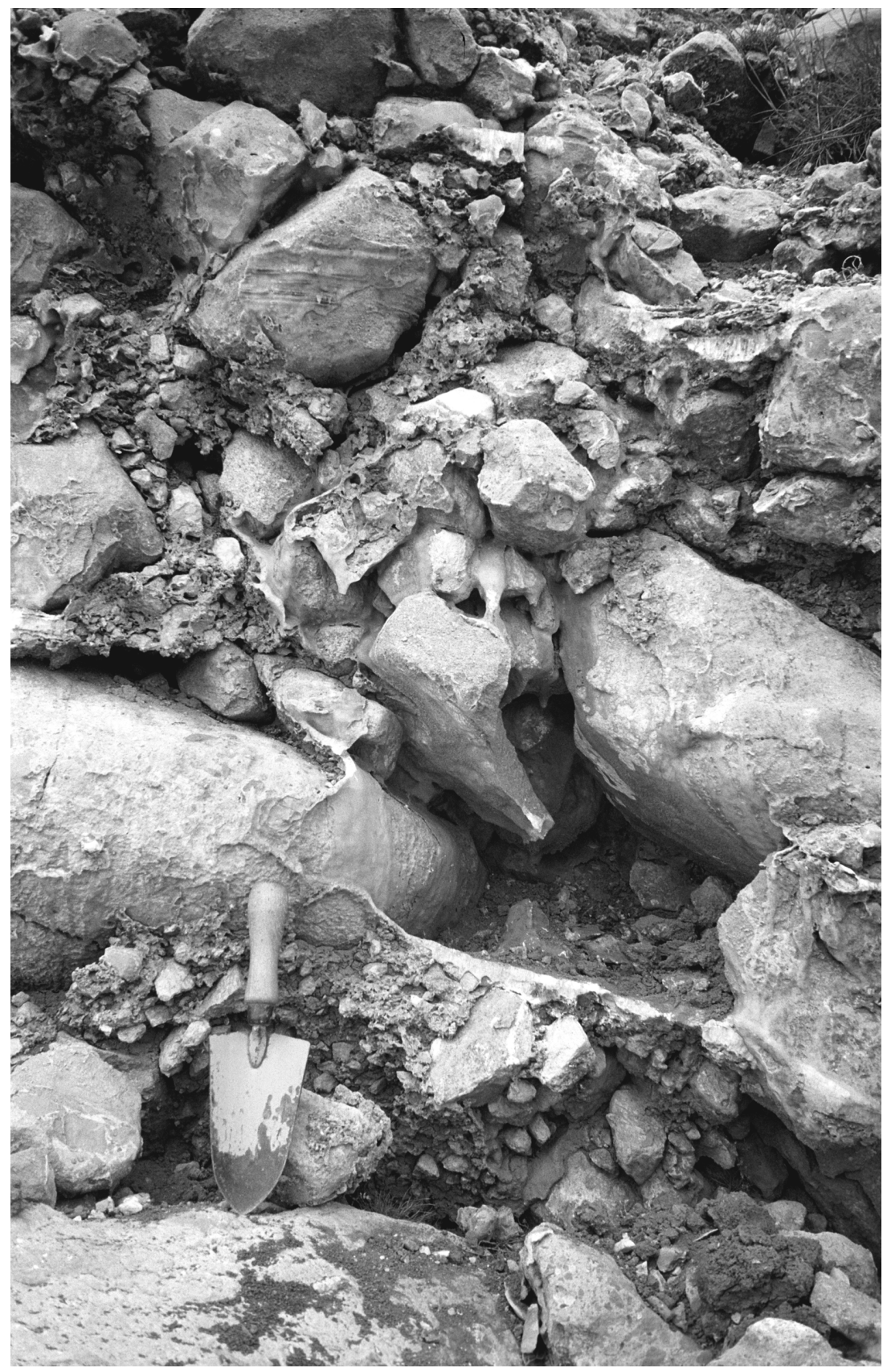

Fig. 12.13. Cemented till on Mount Tymphi, Greece, that has yielded ages $>350,000$ years BP using U-series (Woodward et al. 2004, Hughes et al. 2006b) (photo: Philip Hughes). the western slopes were first traced by Liedtke (1962). Near the Adriatic coast on Mount Orjen (1,895 m a.s.l.), glacial cirques and valleys exploited older karstic forms to form extensive glaciers (Penck 1900; Sawicki 1911; Menkovic et al. 2004). The extensive glaciation on Mount Orjen $(1,895 \mathrm{~m})$ was probably a function of very high precipitation and today modern values here exceed 5,000 mm per year (Magaš 2002).

Marjanac and Marjanac (2004) reviewed the evidence for glaciation in the coastal Dinaric Alps of 
TABLE 12.2. Correlation table showing the relationship between the fragmentary glacial sequence in the Pindus Mountains, Greece, and the continuous lacustrine parasequence in the nearby loannina 249 and 284 cores (Chapter 4)

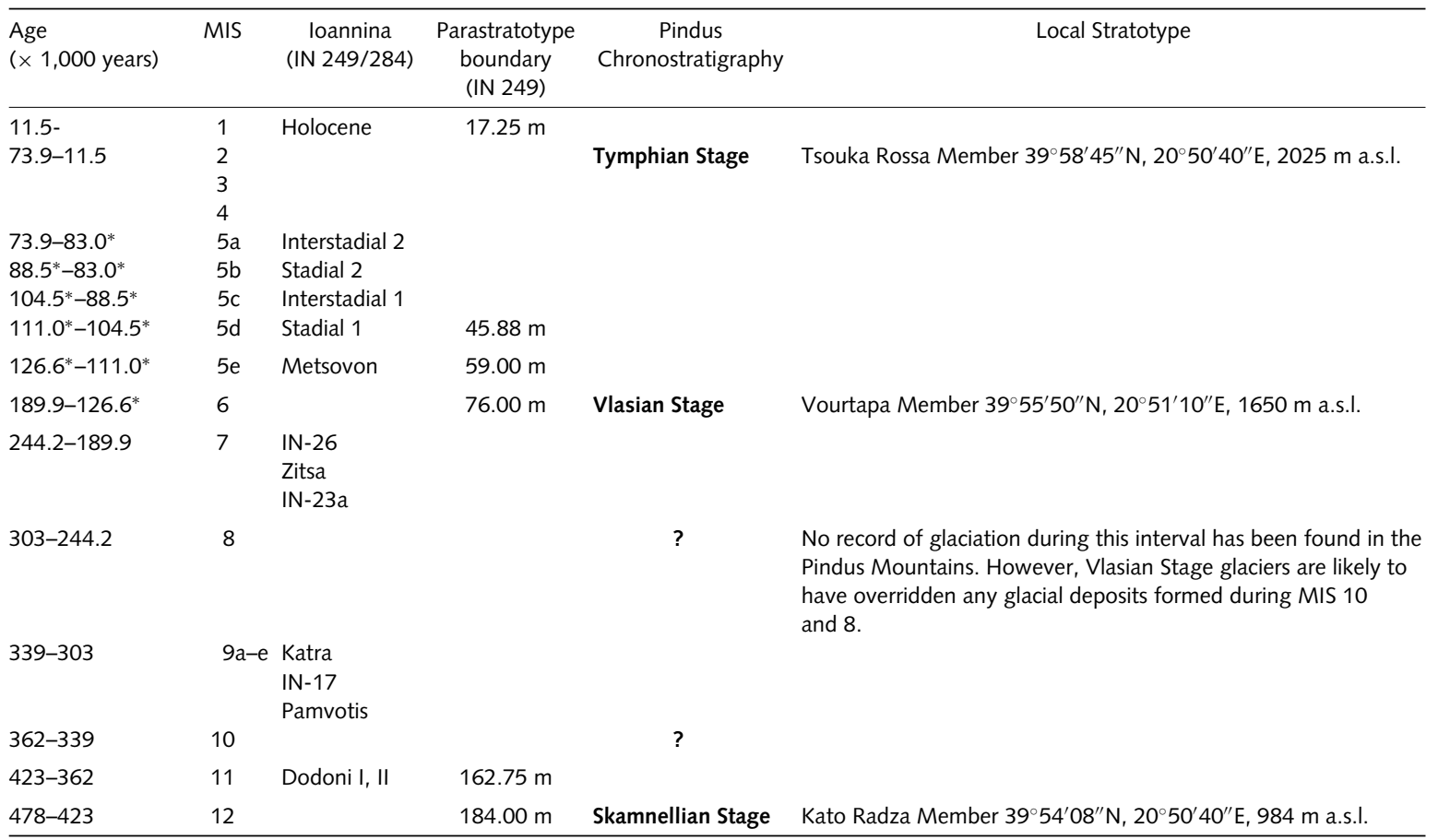

Note: MIS = Marine Isotope Stage.

Names in the third column based on Tzedakis et al. (2002)—all other names for the Ioannina sequence are from Tzedakis (1994).

* Interval dates from Tzedakis et al. (2002) — all other dates from orbitally tuned marine isotope records (Imbrie et al. 1984, Martinson et al. 1987) (from Hughes et al. 2005).

Sources: Tzedakis (1994); Tzedakis et al. (2002).

Croatia. They describe features on some of the Croatian coast and islands in the Adriatic, which they argue are glacial in origin. These include kame-terraces on the Krk and Pag islands to the west of the Velebit Mountains, as well as glacial and periglacial deposits on the mainland coast nearby at Novigradsko More and Karinsko More. They (ibid.) attribute the coastal glacial deposits to a glaciation during the Early or Middle Pleistocene, but have acknowledged that more work is needed to clarify the chronology of the Croatian glacial sequences. Whatever the age of the glacial deposits, their presence at such low altitudes in the Mediterranean is of major significance.

\section{The Italian Appenines}

The most comprehensive geochronological framework for the Pleistocene glacial sequence in the Italian
Appenines is in the Gran Sasso. Here, based on the radiocarbon dating of ice-dammed lacustrine sediments, Giraudi and Frezzotti (1997) have demonstrated that the maximum glacier extent of the last cold stage (Würmian) occurred prior to $22,680 \pm 630{ }^{14} \mathrm{C}$ years BP. At the glacier maximum, ice in the Campo Imperatore area of the Gran Sasso extended $10.5 \mathrm{~km}$ down-valley and covered an area of $19 \mathrm{~km}^{2}$ with an ELA of $c .1,750 \mathrm{~m}$. A series of recessional moraines and rock glaciers in the Gran Sasso are thought to correspond to periods of glacier stabilization or readvance between 20,000 and $10,000{ }^{14} \mathrm{C}$ years BP.

Based on rock glacier evidence, Giraudi and Frezzotti (1997) concluded that mean annual temperatures during the Last Glacial stage were 7.3 to $8.3^{\circ} \mathrm{C}$ lower than today. They extrapolated this temperature depression to the ELA of the contemporaneous valley glacier in the Campo Imperatore area and, based on the well-established relationship between accumulation and 


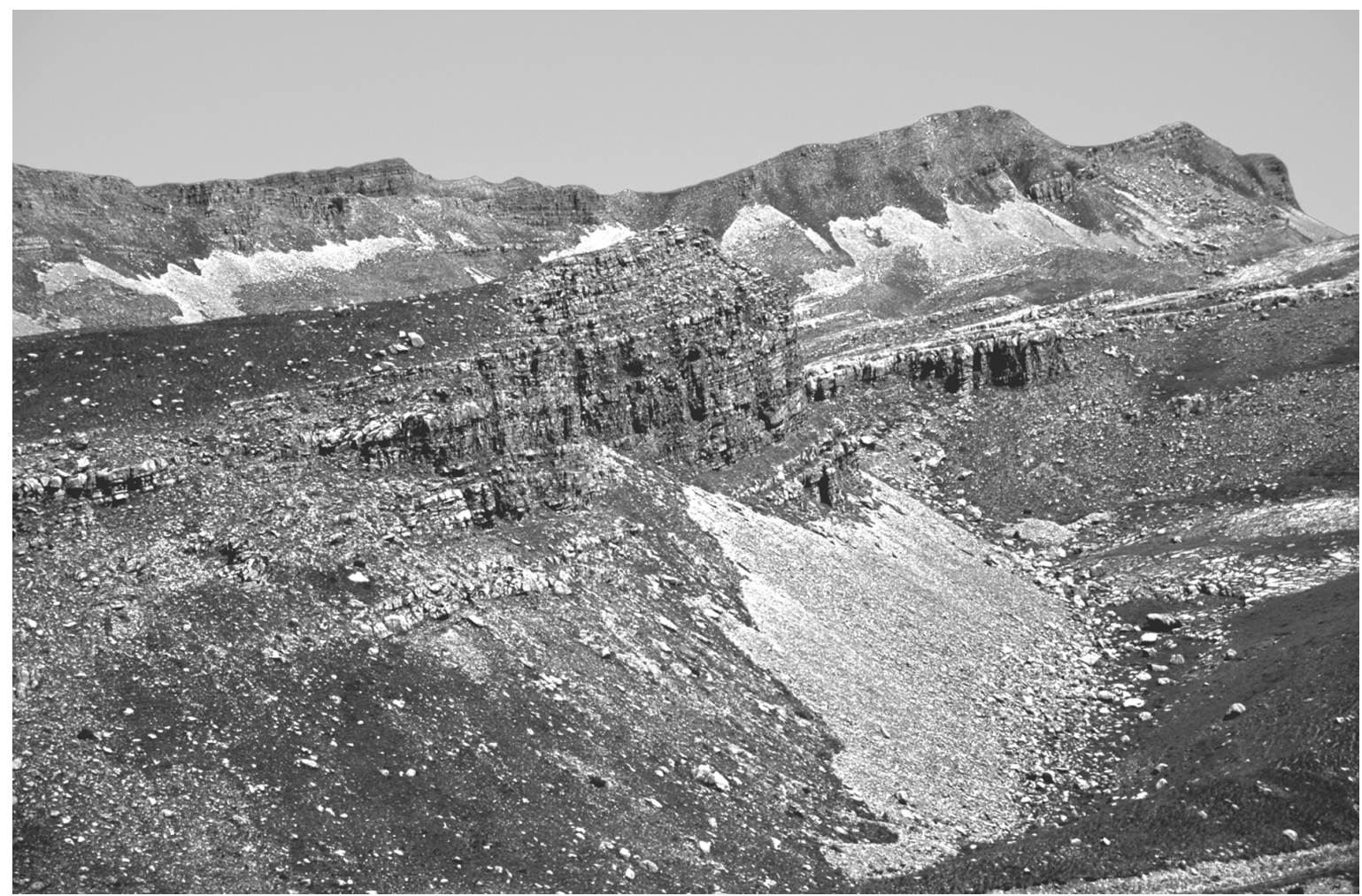

Fig. 12.14. Well-developed screes within the limits of Vlasian Stage glaciers (Figure 12.15, Table 12.2) on the southern slopes of Mount Tymphi, Greece (photo: Jamie Woodward).

precipitation at the ELA of modern glaciers (cf. Ohmura et al. 1992), they concluded that snowfall was similar to today.

In this area Middle Pleistocene glacial deposits are usually less well preserved and are often strongly eroded with a much less pronounced morphology. Kotarba et al. (2001) presented U-series ages for calcite cements within moraines of $135,000 \pm 10,000 \mathrm{cal}$. years BP. Thus, given that the cements formed after the deposition of the host glacial deposits, the moraines were correlated with the Rissian Stage of the Alps (Kotarba et al. 2001). At least two major glacial advances are recorded in the Gran Sasso area, with readvance also recorded during the Würmian Late Glacial.

Glacial deposits that extend lower than moraines assigned to the Würmian Stage have been noted in many other areas of the Italian Apennines but they are commonly fragmentary and their age has not been established (Federici 1980). As in the Campo Imperatore area, they are often partially cemented and show evidence of prolonged weathering.

\section{Corsica}

Glacial features in the mountains of Corsica were first reported by Pumpelly (1859) and the most recent published studies include those by Heybrock (1954), Letsch (1956), and Conchon (1978, 1986). In contrast to many of the glaciated mountains in the Mediterranean, those in Corsica are formed in granite, and because of the resistant nature of this lithology, the cirques, arêtes, and roches moutonées are particularly pronounced and well preserved. Evidence obtained from sediment cores, collected up-valley of the most recent moraines, has shown that the highest cirques contained small glaciers between 15 and $14,000{ }^{14} \mathrm{C}$ years BP, but have been free of ice since the Allerød Interstadial at $c .12,500{ }^{14} \mathrm{C}$ years BP (Conchon 1986).

Kuhlemann et al. (2005) have used geomorphological evidence to reconstruct the Pleistocene glaciers of Corsica. Large ice fields and valley glaciers formed during the Würmian glacial maximum and some glaciers were 


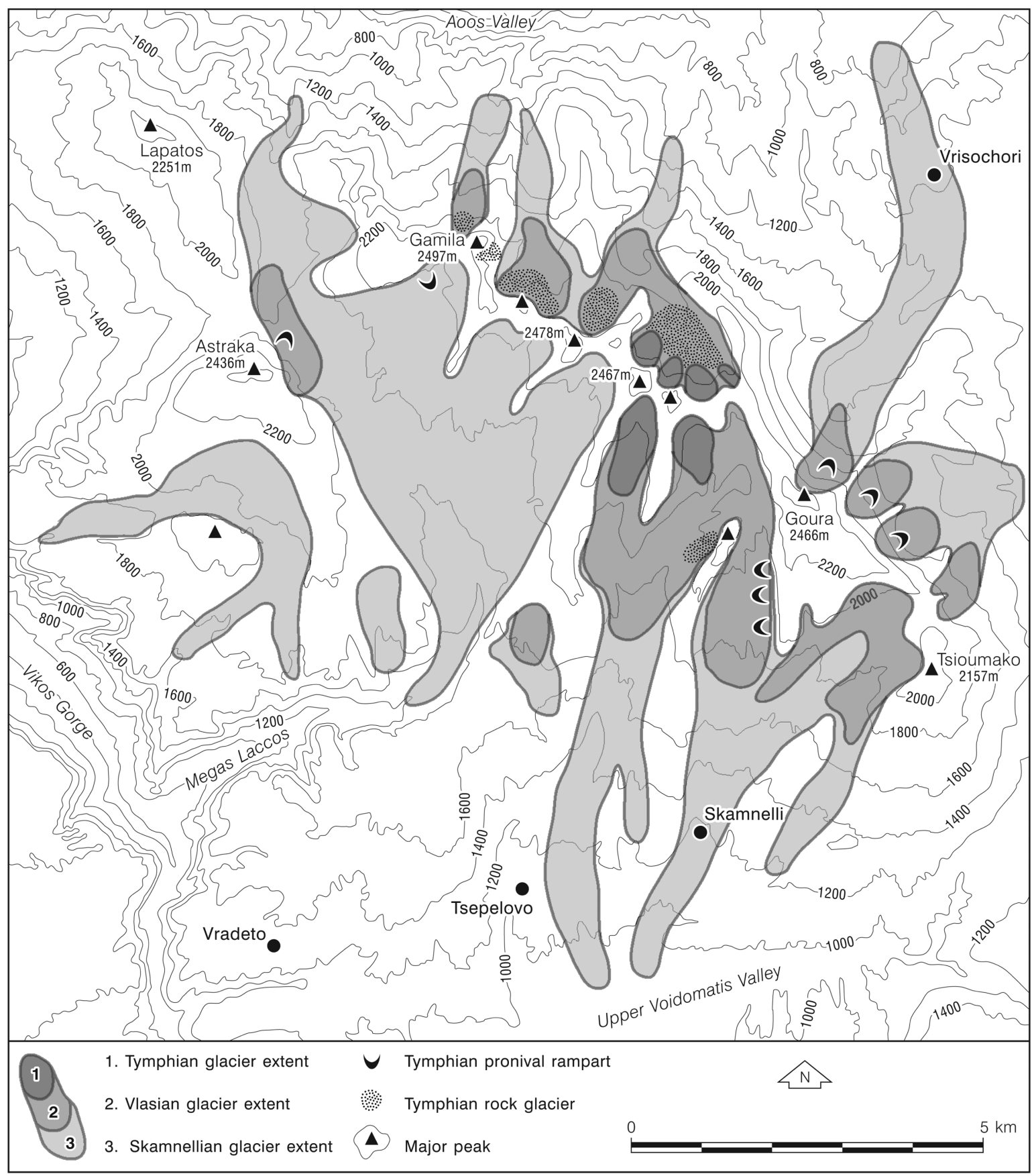

Fig. 12.15. The extent of Middle and Late Pleistocene glaciers on Mount Tymphi, Greece. 
Philip Hughes and Jamie Woodward
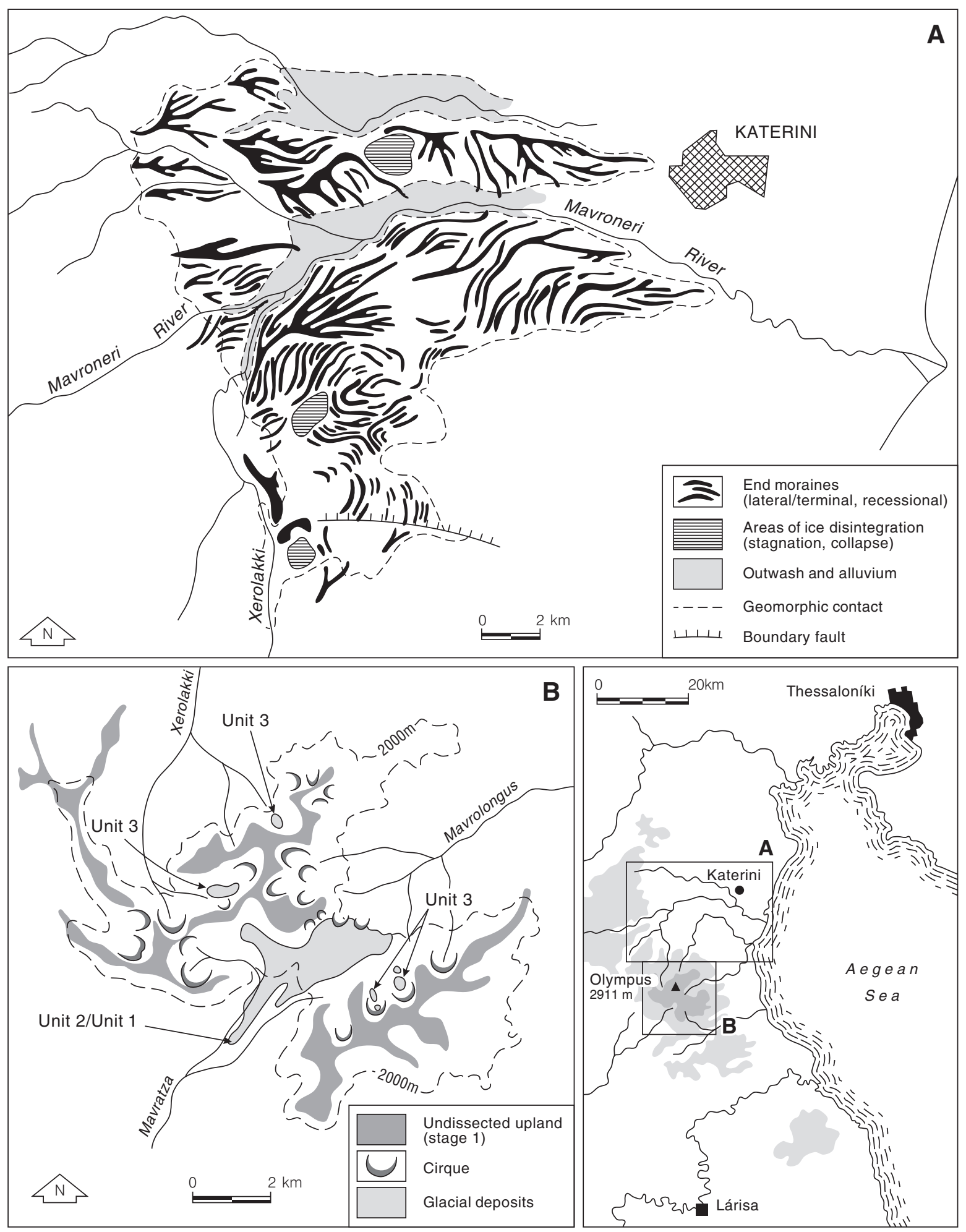

Fig. 12.16. Glacial geomorphological maps of Mount Olympus, north-eastern Greece (modified from Smith et al. 1997). 


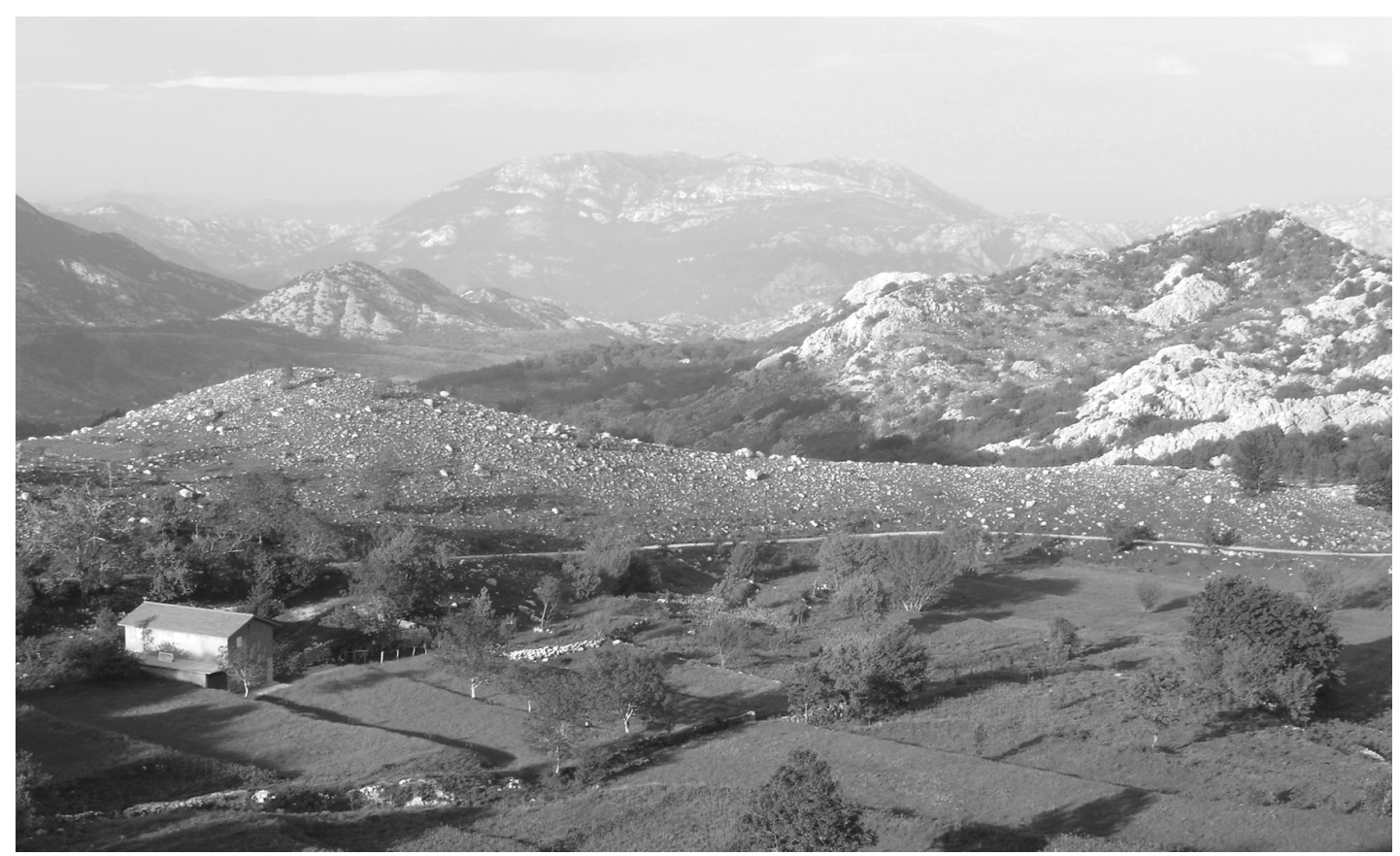

Fig. 12.17. Moraines at c.1,000 m a.s.l. in Duboki Do, above the village of Ubli on Mount Orjen, Montenegro (photo: Philip Hughes).

up to $14 \mathrm{~km}$ long. The ELA of the Würmian glaciers was between 1,400 and $1,750 \mathrm{~m}$, with variations attributed to precipitation differences. Mean annual temperatures during the Würmian glacial maximum were $8^{\circ} \mathrm{C}$ lower compared with modern values. This finding is similar to recent data from Greece, but good dating control has not been firmly established for the bulk of the Coriscan glacial record. Cosmogenic isotope exposure dating offers much potential as preliminary investigations have shown that the Corsican granites are suitable for this method (Hewitt 2002).

\section{The Alpes Maritimes}

During the Würmian Stage, the Alpes Maritimes were covered by ice that was contiguous with the main Alpine ice sheet-extending over an area of $c .126,000 \mathrm{~km}^{2}$ (Ehlers 1996). The glacial geomorphology of the Argentera area has been described by Ribolini (1996). The valleys of this area are deeply scoured and large moraines were deposited in their lower parts. The Würmian glacial maximum in the Alps occurred between c. 28,000 and $20,000{ }^{14} \mathrm{C}$ years $\mathrm{BP}$ in the northern Alps and at c.20,000 to $18,000{ }^{14} \mathrm{C}$ years BP in the southern Alps (Florineth and Schlüchter 2000). Lacustrine sediments at Lac Long Inférieur, a glaciated cirque
(2,090 $\mathrm{m}$ a.s.l.) in the Alpes Maritimes, indicate that the ice had melted by $14,190 \pm 130^{14} \mathrm{C}$ years BP (Ponel et al. 2001). However, in the Argentera Massif, Fisinger and Ribolini (2001) document evidence for several glacial advances during the Late Glacial Substage. Granger et al. (2006) present ${ }^{10}$ Be cosmogenic ages of $16.3 \mathrm{ka}$ and $18.8 \mathrm{ka}$ respectively for two moraines in the Gesso Valley and argue that they were part of the same glacial phase. The application of exposure age dating at higher elevations in the Gesso Valley has led to the recognition of moraines of the Younger Dryas age (Federici et al. 2008).

\section{The Pyrenees}

The Pyrenees were extensively glaciated during the Pleistocene, a fact recognized in pioneering research in the early nineteenth century by Albrecht Penck (1885). These glaciations have been attributed to at least two Pleistocene cold stages - the oldest deposits are correlated to the Rissian Stage and a second, higher, suite of deposits to the Würmian Stage (Barrère 1963). The largest and most powerful Pleistocene glaciers formed on the northern slopes of the Pyrenees in 


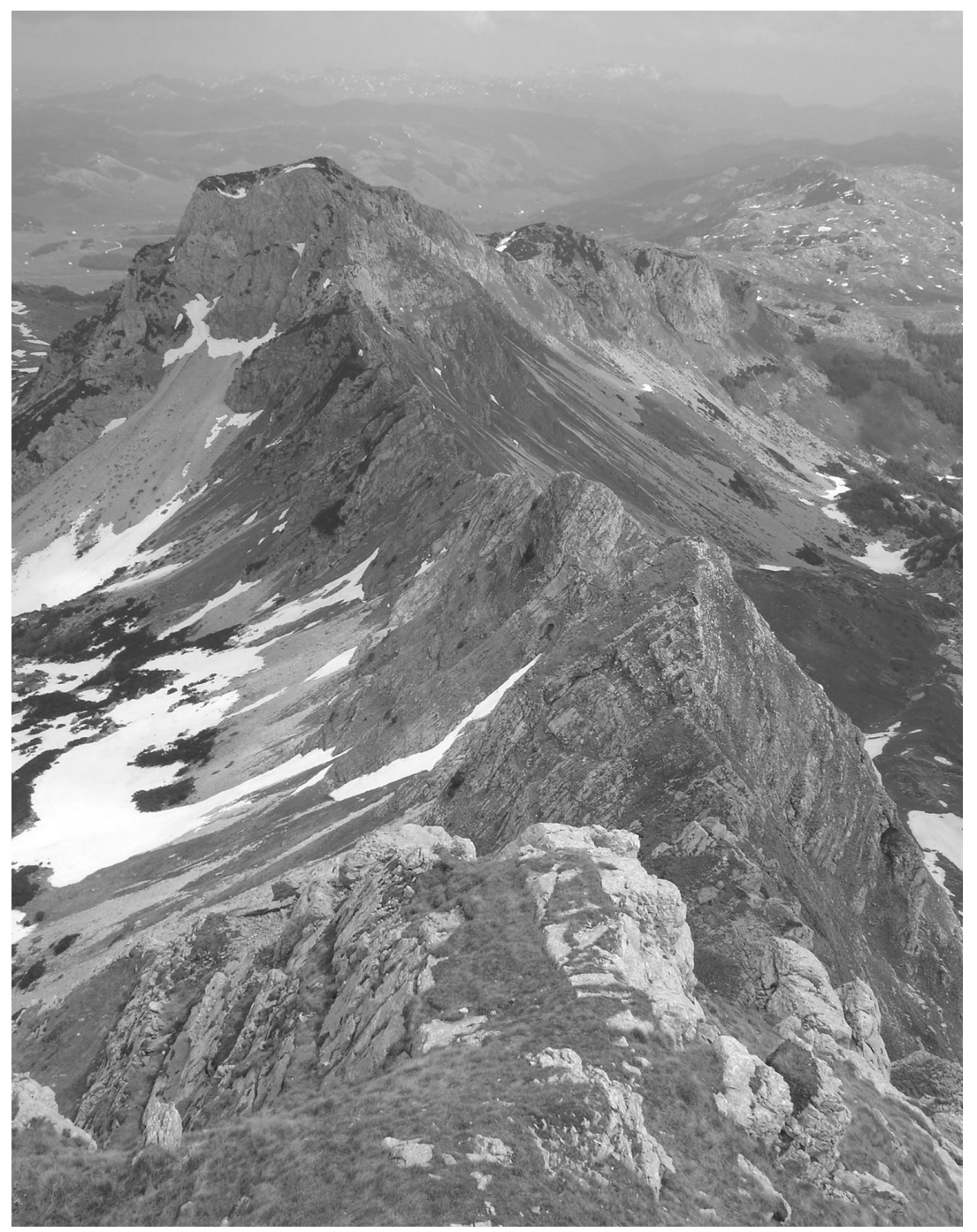

Fig. 12.18. Glacial arête between the peaks of Sedlena Greda $(2,227 \mathrm{~m}$ a.s.I.) and Ranisava (2,081 $\mathrm{m}$ a.s.I.) in the Durmitor mountain area, Montenegro (looking south-east from the summit of Sedlena Greda). This ridge separated two major Pleistocene ice flows from the central Durmitor area (photo: Philip Hughes).
France (Calvet 2004). In the Ariège valley, for example, glaciers extended $65 \mathrm{~km}$ to an altitude of $370 \mathrm{~m}$ a.s.l. (Hérail et al. 1986). The chronology of the last (Würmian) glaciation in the French Pyrenees is based on sedimentological and palynological studies and radiocarbon dating of lacustrine sediments near former glacier margins. This approach has indicated that, during the last glaciation, the glacial maximum in the French Pyrenees was before $38,000{ }^{14} \mathrm{C}$ years $\mathrm{BP}$ (Hérail et al. 1986; Jalut et al. 1992). This is also the case in the Vosges Mountains of Alsace (Seret et al. 1990).

In the Spanish Pyrenees, most glacial deposits are thought to have formed during the last glaciation, although some isolated glacial deposits have been attributed to earlier periods (Calvet 2004). However, in common with French Pyrenees, the geochronology of the glacial sequences in the Spanish Pyrenees is poorly defined. Correlations have been made on the basis of morphostratigraphical comparisons, and, even delimiting the maximum extent of the last glaciation remains one of the most significant problems of Pyrenean Quaternary geology (García-Ruiz et al. 2003). Nevertheless, it is significant to note that there is evidence that the maximum extent of ice during the Last Glacial stage occurred significantly earlier than for the major ice sheets of Britain and Scandinavia, which reached their 
maximal extents between 21,000 and $18,000{ }^{14} \mathrm{C}$ years BP (Sibrava et al. 1986). Data from various sources suggest that the maximum extent of glaciation during the Last Glacial phase occurred before $30,000{ }^{14} \mathrm{C}$ years BP (García-Ruiz et al. 2003), similar to findings in the French Pyrenees to the north. However, recent ${ }^{10} \mathrm{Be}$ dates from glacial boulders and rock surfaces conflict with the idea of an early glacier maximum. Pallàs et al. (2007) found that the ${ }^{10} \mathrm{Be}$ dates suggest that the major phase of moraine building in the south-central Pyrenees occurred after 25,000 cal. years вP. Further work using multiple dating techniques is needed to clarify this issue.

Deglaciation in the Pyrenees was staggered by a phase of upper valley glaciation between 16,000 and 15,000 ${ }^{14} \mathrm{C}$ years BP and then by a phase of cirque glaciation between 14,000 and 13,000 ${ }^{14} \mathrm{C}$ years BP (Bordonau 1992). The last phase of Pleistocene glaciation is represented by moraines and rock glaciers close to the cirque backwalls and may date from the Younger Dryas between 11,000 and $10,000{ }^{14} \mathrm{C}$ years BP (Serrat 1979), in accord with the Alpes Maritimes and the Italian Apennines.

In many valleys of the Pyrenees, Würmian Stage glaciers appear to have removed much of the older glacial deposits. However, in some locations, traces of earlier and more extensive glacial deposits exist and these may relate to the Rissian Stage (MIS 10-6) (Barrère 1963). In the eastern Pyrenees, strongly weathered tills are present at lower elevations than those ascribed to the Rissian Stage and are considered to have formed during the early Middle Pleistocene (Calvet 2004). However, the geochronology of the pre-Würmian record is yet to be defined and this is a key issue across much of the Mediterranean region.

\section{Iberia}

Pleistocene glaciation took place in many of the high mountain areas of Iberia and these are reviewed in Hughes et al. (2006a). Most of the glacial sequences have not been dated, and, given the large number of glaciated sites, only those studies where progress has been made in understanding the geochronology of the glacial record are discussed below. Even though many of the glaciated basins on the Iberian Peninsula do not drain to the Mediterranean Sea, they are located in the same latitudinal belt as the other glaciated terrains discussed in this review and they provide a valuable source of comparison.

Some geochronological control is available to the west of the Picos de Europa of northern Spain, in the Redes
Natural Park. Here, the most extensive glacial phase was characterized by an ice field with outlet glaciers extending up to $5 \mathrm{~km}$ in length. These glaciers descended to $c .950 \mathrm{~m}$ with snowlines at $c .1,550 \mathrm{~m}$. Radiocarbon dating suggests that the maximum phase of glaciation during the Last Glacial stage in this area occurred prior to c.40,000 ${ }^{14} \mathrm{C}$ years BP (Jiménez-Sánchez and Farias 2002). Again, this is well before the global Last Glacial Maximum (LGM), which occurred around 18,000 ${ }^{14} \mathrm{C}$ years BP (CLIMAP Project Members 1976). Glacial landforms have been dated using ${ }^{36} \mathrm{Cl}$-based cosmogenic exposure dating in the Sierra de Gredos and Sierra de Guadarrama in central Spain (Palacios et al. 2007). These ages put the local glacier maximum around $21 \mathrm{ka}$, about the time of the global LGM of MIS 2.

Other dated glacial sequences in Iberia include those in the Serra de Queira and Serra de Gêrez in Galicia and northern Portugal (Figure 12.1). Here, Fernadez Mosquera et al. (2000) applied ${ }^{21} \mathrm{Ne}$ cosmogenic dating to glacially polished surfaces and push-moraine boulders and three glacial phases have been identified. The oldest was dated to before $c .238,000 \mathrm{cal}$. years BP, an intermediate phase to $c .130,000 \mathrm{cal}$. years $\mathrm{BP}$, and the youngest to c.15,000 cal. years BP. This sequence of three major Pleistocene glaciations is comparable to the geochronologies established in Italy and Greece (Giraudi and Frezzotti 1997; Kotarba et al. 2001; Woodward et al. 2004; Hughes et al. 2006b) although the oldest glacial phase appears to be younger than that recorded in Greece and may correspond to a glaciation during the early Rissian (MIS 8).

Further south, in the Serra da Estrela of Portugal $(1,991 \mathrm{~m})$ (Figure 12.1), glaciation was characterized by the development of a plateau ice cap which fed diffluent glaciers, the longest of which was $13 \mathrm{~km}$ and attributed to the Würmian Stage by Daveau (1971). Thermoluminescence ages from fluvioglacial units of between $16.6 \pm 2.5$ and $10.6 \pm 1.6 \mathrm{ka}$ suggest glacial activity in this area during the Late Glacial (Vieira et al.2001).

\section{The Atlas Mountains}

Quaternary glacial and periglacial features are present throughout the Atlas Mountains of north-west Africa. However, little is yet known of the timing and extent of glaciation in the area (cf. Hughes et al. 2004). Glacial features including cirques, troughs, roches moutonées, riegels, and moraines have been reported from the High Atlas and Pleistocene snowlines have been placed between 3,700 and 3,300 m (Heybrock 1953; Awad 1963; Hughes et al. 2004). The highest peaks in the 
TABLE 12.3. Current understanding of the geochronology of Pleistocene glacial deposits in the Mediterranean region

\begin{tabular}{|c|c|c|}
\hline $\begin{array}{l}\text { Marine Isotope } \\
\text { Stage }\end{array}$ & $\begin{array}{l}\text { Alpine/ Northern Europe } \\
\text { Chronostratigraphy }\end{array}$ & Region and approximate age of glacial units \\
\hline 2 & Würmian/ Weichselian & $\begin{array}{l}\text { Italy: }>22,000^{14} \mathrm{C} \text { years } \mathrm{BP}^{1} \text { (radiocarbon) } \\
\text { Pyrenees: }>38,000^{14} \mathrm{C} \text { years } \mathrm{BP}^{2} \text { (radiocarbon) } \\
\text { Iberia: }>29,000^{14} \mathrm{C} \text { years } \mathrm{BP}^{3} \text { (radiocarbon); }>15,000 \text { years }{ }^{4}\left({ }^{21} \mathrm{Ne}\right. \\
\quad \text { cosmogenic) } \\
\quad 21,000 \text { years }{ }^{5}\left({ }^{36} \mathrm{Cl} \text { cosmogenic) }\right. \\
\text { Alpes Maritimes: } 19,000 \text { years }{ }^{6}\left({ }^{10} \text { Be cosmogenic) }\right. \\
\text { Turkey: } 26,000 \text { years }{ }^{7}\left({ }^{10} \text { Be cosmogenic); } 20,000 \text { years }{ }^{8}\left({ }^{36} \mathrm{Cl} \text { cosmogenic) }\right.\right.\end{array}$ \\
\hline 6 & Late Rissian/ Saalian & $\begin{array}{l}\text { Greece: }>120,000 \text { years }^{9}(U \text {-series }) \\
\text { Italy: }>130,000 \text { years }{ }^{10}(U \text {-series }) \\
\text { Iberia: }>130,000 \text { years }^{4}(21 \mathrm{Ne} \text { cosmogenic })\end{array}$ \\
\hline 8 & Early Rissian/ Saalian & Iberia: $>230,000$ years ${ }^{4}\left({ }^{21} \mathrm{Ne}\right.$ cosmogenic) \\
\hline 12 & Mindelian/ Elsterian & Greece: $>350,000$ years $^{9}(\mathrm{U}$-series $)$ \\
\hline
\end{tabular}

${ }^{1}$ Giraudi and Frezzotti (1997): Jalut et al. (1992). ${ }^{2}$ García-Ruiz et al. 2003. ${ }^{3}$ Jiménez-Sánchez and Farias (2002). ${ }^{4}$ Fernandez Mosquera et al. (2000). ${ }^{5}$ Palacios et al. (2007). ${ }^{6}$ Granger et al. (2006). ${ }^{7}$ Akçar et al. (2007), Akçar et al. (2008). ${ }^{8}$ Sarıkaya et al. (2008). ${ }^{9}$ Hughes et al. (2004); Hughes et al. (2006d); Woodward et al. (2004). ${ }^{10}$ Kotarba et al. (2001).

Middle Atlas also show evidence of former glaciation and the regional snowline is estimated at $c .2,800 \mathrm{~m}$ a.s.l. during the most extensive glacial phase (Raynal et al. 1956; Awad 1963). Periglacial features are also present. Stone polygons, solifluction features, and rock glaciers have been described on Bou Iblane and Jbel BouNaceur, in the Middle Atlas (Raynal 1952; Dresch and Raynal 1953; Awad 1963).

Glacial features have also been noted in the Djurdjura Massif (2,308 m) of the Algerian Tell (Figure 12.1) where Barbier and Cailleux (1950) identified cirques, Ushaped valleys, and terminal moraines. To the southeast, in the Aurès Massif, Ballais (1983) noted the presence of moraines above $1,600 \mathrm{~m}$ on Jbel Ahmar Khaddou (2,017 m a.s.l.) and Jbel Mahmel (2,321 m a.s.l.). However, the chronology of glaciation in these areas and elsewhere in the Atlas Mountains has not been established and this remains the biggest obstacle to an improved understanding of the glacial history of northwest Africa.

\section{Pleistocene Overview}

It is clear that very substantial ice masses formed in many Mediterranean mountain areas during Pleistocene cold stages. The glacial deposits and landforms they produced represent important archives of environmental change. However, until quite recently good dating frameworks (Table 12.3) and detailed stratigraphical frameworks had not been established in many key areas. A clear pattern is now emerging whereby the oldest and most extensive glacial deposits and landforms date from the Middle Pleistocene. In fact, in some areas, at least two phases of Middle Pleistocene glaciation have been identified during intervals equivalent to the Saalian and Elsterian Stages of northern Europe (e.g. Fernadez Mosquera et al. 2000; Woodward et al. 2004; Hughes et al. 2006a, $b$ ).

Where sound stratigraphical frameworks supported by a robust geochronology do exist for the last cold stage, it has become apparent that glacier maxima in many parts of the Mediterranean mountains preceded the global LGM of MIS 2 by more than 10,000 years (Hughes and Woodward 2008).

The small mountain glaciers of the Mediterranean would have advanced and decayed rapidly in response to mass balance fluctuations and they reached their maximum during the last cold stage well before the large ice sheets that covered the Alps and northern Europe. Increased aridity in southern Europe, caused by a strengthening of high pressure systems over the expanding Alpine and north European ice sheets, would have forced glacier retreat in the Mediterranean mountains. The situation is also likely to have been complicated by millennial-scale climate changes recorded in the Greenland ice sheet (Dansgaard et al. 1993) and mirrored in long lacustrine pollen sequences in Italy and Greece (Allen et al. 1999; Tzedakis et al. 2004; Chapter 4). This has been highlighted for the mountain glaciers of Greece by Hughes et al. (2006d) who recognized the potential for multiple phases of glacier advance and retreat during the Last Glacial cycle (Figure 12.19). This analysis identified ten periods, between 115 and 


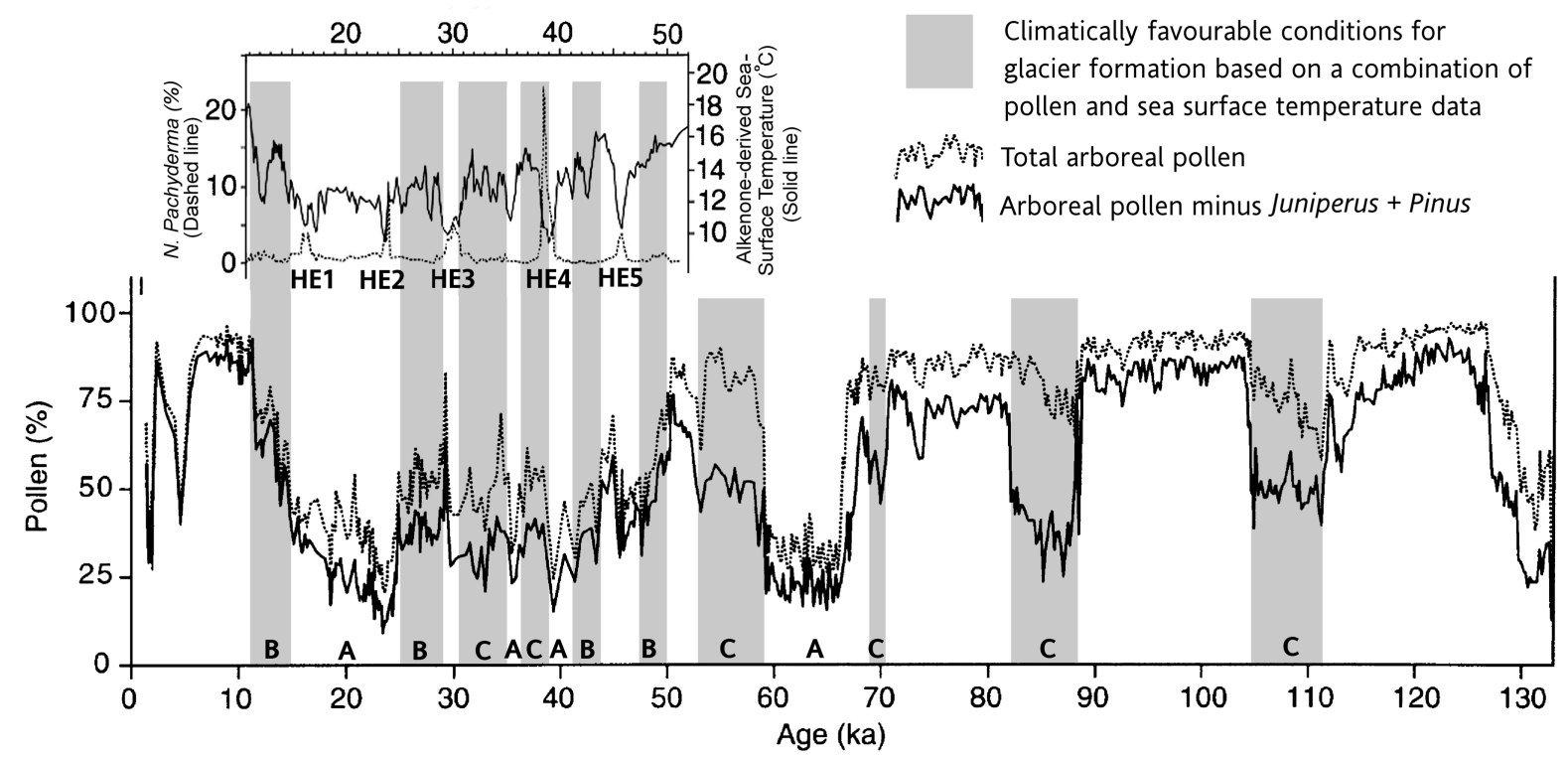

Fig. 12.19. Climatically favourable conditions for glacier formation based on a combination of pollen and sea surface temperature data. Summary pollen percentage curves from the loannina I-284 sequence in north-west Greece, spanning the Last Glacial cycle. Potential intervals suitable for glacier formation are indicated by letters A: major stadials characterized by low arboreal pollen, both including and excluding Pinus and Juniperus; B: intermediate phases between the apices of major stadials and interstadials; and C: intervals characterized by large differences between total arboreal pollen frequencies and arboreal pollen frequencies, excluding Pinus and Juniperus. All other intervals represent major interstadials or interglacials. Both B and C types-the more favourable conditions for glaciation-are indicated by shading. The upper graph depicts variations in the percentage of Neogloboquadrina pachyderma (sinistral) and alkenone-derived seasurface temperatures in marine core MD95-2043 from the Alboran Sea, in the western Mediterranean (from Hughes et al. (2006d).

$10 \mathrm{ka}$, when the climate would have favoured glacier development. The timing of the glacier maxima during earlier glaciations is unclear at present, although large glaciers in the Mediterranean may have been less responsive to rapid climate changes in comparison to those that existed during the last cold stage. Recently published data from Greece show that the transition from glacial to non-glacial conditions took place very rapidly at the end of the last cold stage (Woodward et al. 2008).

\section{Glacial and Periglacial Interactions with Other Geomorphological Systems}

Glacial and periglacial systems may exert considerable influence on other environments, especially downstream fluvial systems as has been shown for Mount Tymphi, in the Pindus Mountains, where Pleistocene glaciation was a major influence on the longterm behaviour of the Voidomatis River (Chapter 11).
Fluvial sediments transported during cold stages were dominated by materials from the glaciated upland terrains (Bailey et al. 1990; Lewin et al. 1991; Woodward et al. 1992, 1995; Hamlin et al. 2000). The interaction of glacial and fluvial systems has also been explored in the Pineta basin of the central Spanish Pyrenees by Jones (2000).

Glaciers and their meltwaters have enhanced karstic processes in many upland areas. In proglacial areas, dolines may be found concentrated in clusters outside terminal moraines (Waltham 1978). Where glaciers occupy only the highest valley and cirque areas, meltwaters often discharge underground before emerging as springs at lower elevations. This process is evident in front of modern and former glaciers in the Pyrenees and was termed 'Pyrenean type' glacio-karst by Ford and Williams (1989). This process has also been observed at the Zeleni Sneg glacier, on Triglav in Slovenia, where meltwater disappears through a 280-m deep pothole and resurfaces $1.25 \mathrm{~km}$ down-valley (Gams 2001). The deepest potholes in the world have formed in glaciated mountain areas such as the Pyrenees, Alps, 
and Caucasus (ibid.; Chapter 11). Karstic hollows, such as dolines, often promote snow accumulation and can contribute to glacier development. The interaction of glacial and karstic processes is an important and distinctive component of the physical geography of the Mediterranean mountains.

Paraglacial effects have also been reported in the region. For example, Lebourg et al. (2003) discussed the importance of high mountain landslides and their sliding mechanisms using a case study of the glaciated Aspe Valley of the Pyrenees. They noted that slope failures occur most frequently where glacial deposits remain and generally at the junction between the till and the underlying strata (Chapter 6). Unstable landslide-prone slopes are likely to be a legacy of glaciation in many Mediterranean mountains, especially where glaciers have retreated during the Holocene and in areas of recent permafrost melting. Over longer timescales, Woodward et al. (2008) have argued that the major Middle Pleistocene glaciations in the Pindus Mountains were responsible for delivering such large volumes of sediment to the fluvial system that reworking of these materials was a major control on river behaviour throughout the Late Pleistocene and Holocene.

Finally, periglacial processes also play an important role in a range of geomorphological and sedimentary systems, particularly in terms of debris supply. Frost action can deliver significant quantities of sediment to talus slopes and fluvial systems and frost shattering of rockshelter walls can be an important mechanism of coarse debris accumulation during glacial periods (Woodward 1997; Karkanas 2001 Chapter 6). Thus, even if all the remaining Mediterranean glaciers and areas of permafrost disappear in the next few decades, their legacy will remain, not just as a relict geomorphological record, but also in shaping the sediment supply dynamics in colluvial and fluvial systems.

\section{Conclusions}

Active glacial and periglacial environments are present in several of the highest mountains in the Mediterranean and cryospheric processes been shown to have major impacts on geomorphological systems and biotic communities throughout the upland zone (above $500 \mathrm{~m}$ ). However, it is clear that glacial and periglacial environments are becoming increasingly marginal in this region and most glaciers in the Mediterranean mountains appear to be in retreat. There is no documented evidence of sustained glacier advance in recent decades and, given current climatic trends (Chapter 3), it is possible that many glaciers will disappear in the twenty-first century. Unfortunately, in many areas, such as in Montenegro and Albania, few detailed studies have been made of recent glacier activity and further work is necessary to understand fully recent glacier dynamics across the Mediterranean (Hughes 2007).

Permafrost is present in only the highest Mediterranean mountains and is especially susceptible to minor climatic variations (Gómez et al. 2001). Sporadic and discontinuous permafrost has been identified in the Sierra Nevada and Picos de Europa of Spain, the Pyrenees, the Alpes Maritimes, the Italian Apennines, the Julian Alps, and the Pontic and Taurus Mountains and periglacial processes such as nivation are present in many more mountains. These periglacial environments are also likely to diminish in the Mediterranean mountains during the twenty-first century. It is also clear that climate change will have major implications for high-mountain ecosystems in the Mediterranean region, where plants and animals adapted to cold, alpine conditions now face higher temperatures and a surge of predators and competitors (Krajick 2004; Chapter 23).

Whilst contemporary glacial and periglacial environments in most Mediterranean mountains are becoming increasingly rare, the legacy of past cold conditions is widely recorded and often exceptionally well preserved. Pleistocene glacial features such as cirques, U-shaped valleys, limestone pavements, and moraines often dominate upland landscapes. These are closely associated with karstic processes in limestone uplands. A key advance of the last decade has been the wider application of radiometric dating and this has shown that glaciers were active in many areas during the Middle and Late Pleistocene. Periglacial features such as rock glaciers, scree formations, and frost-shattered bedrock are also key landscape elements in many upland areas.

\section{References}

Ainsworth, W. F. (1842), Travels and Researches in Asia Minor, Mesopotamia, Chaldea and Armenia. 2 vols. J. W. Parker, London. Akçar, N. and Schlüchter, C. (2005), Paleoglaciations in Anatolia: a schematic review and first results. Eiszeitalter und Gegenwart 55: 102-21.

Yavuz, V., Ivy-Ochs, S., Kubik, P.W., Vardar, M., and Schlüchter, C. (2007), Paleoglacial records from Kavron Valley, NE Turkey: Field and cosmogenic exposure dating evidence. Quaternary International 164-5, 170-83.

Akçar, N., Yavuz, V., Ivy-Ochs, S., Kubik, P.W., Vardar, M., and Schlüchter, C. (2008) A case for a down wasting mountain 
glacier during Termination I, Vercyenik Valley, NE Turkey. Journal of Quaternary Science 23: 273-85.

Allen, J. R. M., Brandt, U., Brauer, A., Hubberten, H. W., Huntley, B., Keller, J., Kraml, M., Mackensen, A., Mingram, J., Negendank, J. F. W., Nowaczyk, N. R., Oberhansli, H., Watts, W. A., Wulf, S., and Zolitschka, B. (1999), Rapid environmental changes in southern Europe during the last glacial period. Nature 400: 740-3.

Almagià, R. (1918), Trace glaciali nelle montagne dell'Albania. Rivista Geografica Italiana 25: 85-95.

Arpat, E. and Özgül, N. (1972), Rock glaciers in Geyik Daği area, central Taurus. Bulletin of the Mineral Research and Exploration Institute of Turkey 78: 28-32.

Awad, H. (1963), Some aspects of the geomorphology of Morocco related to the Quaternary climate. The Geographical Journal 129: 129-39.

Bailey, G. N., Lewin, J., Macklin, M. G., and Woodward, J. C. (1990), The 'Older Fill' of the Voidomatis valley, North-west Greece and its relationship to the Palaeolithic archaeology and glacial history of the region. Journal of Archaeological Science 17: $145-50$.

Ballais, J.-L. (1983), Moraines et glaciers Quaternaires des Aurès Algérie. 108ème Congrès national de Sociétés savantes, Grenoble, 1983, Géographie, 291-303.

Barbier, A. and Cailleux, A. (1950), Glaciaire et périglaciaire dans le Djurdjura occidental Algérie. Comptes Rendus des Séances de l'Académie des Sciences, Paris. Juillet-Décembre 1950, 365-6.

Barrère, P. (1963), La période glaciaire dans l'Ouest des Pyrénéés centrales franco-espagnoles. Bulletin de la Société Géologique de France 5: 516-26.

Bayari, S., Zreda, M., Çiner, A., Nazik, L., Törk, K., Özyurt, N., Klimchouk, A., and Sarikaya, A. M. (2003), The extent of Pleistocene ice cap, glacial deposits and glaciokarst in the Aladaglar massif: central Taurids range, southern Turkey. XVI INQUA Congress, Reno, Nevada, 22-30 July 2003. Abstracts with Programmes, 40-9: 144.

Blumenthal, M. M. (1958), Vom Agri Dag (Ararat) zum Kaçkar Dag. Bergfahrten in nordostanatolischen Glaenzlanden. Die Alpen 34: 125-37.

Boenzi, F., Palmentola, G., Sanso, P., and Tromba, F. (1992), Le tracce glaciali del massiccio dello Smolikas (Catena del PindoGrecia). Rivista Geografica Italiana 99: 379-93.

Bonaparte, Prince Roland (1890), Les variations périodiques des glaciers Français II. Annuaire Club Alpine Français 17: 423-7.

Bordonau, J. (1992), Els complexos glàcios-lacustres relacionats amb el darrer cicle glacial als Pirineus. Dept. de Geologia Dinàmica, Geofísica i Paleontologia, Universitat de Barcelona, Ph.D. thesis. Geoforma Ediciones, Logroño.

Brosche, K. U. (1978), Formas actuales y limites inferiores periglaciares en la Peninsula Iberica. Estudos Geograficos 151: 131-61.

Calvet, M. (2004), The Quaternary Glaciation of the Pyrenees, in J. Ehlers and P. L. Gibbard (eds.), Quaternary GlaciationsExtent and Chronology. Part I: Europe. Elsevier: Amsterdam, 119-28.

Chueca, J. and Julián, A. (2004), Relationship between solar radiation and the development and morphology of small cirque glaciers Maladeta mountain massif, central Pyrenees, Spain. Geografiska Annaler 86A: 81-9.

$-12005)$, Movement of Besiberris rock glacier, Central Pyrenees, Spain: Data from a 10-year geodetic survey. Arctic, Antarctic and Alpine Research 37: 163-70.
_ _ - Saz, M. A., Creus, C., and López, J. I. (2005), Responses to climatic changes since the Little Ice Age on Maladeta Glacier (Central Pyrenees). Geomorphology, 68: 167-82.

Çiner, A. (2004), Turkish Glaciers and Glacial Deposits, in J. Ehlers and P. L. Gibbard (eds.), Quaternary GlaciationsExtent and Chronology. Part I: Europe. Elsevier, Amsterdam, 419-29.

—Deynoux, M., and Çörekcioglu, E. (1999), Hummocky moraines in the Namaras and Susam Valleys, Central Taurids, SW Turkey. Quaternary Science Reviews 18: 659-69.

CLIMAP Project Members (1976), The surface of ice-age earth. Science 191: 1131-7.

Conchon, O. (1978), Quaternary studies in Corsica France. Quaternary Research 9: 41-53.

(1986), Quaternary Glaciations in Corsica. Quaternary Science Reviews 5: 429-32.

Couvreur, G. (1966), Les formations périglaciares du Haut Atlas central Marocaine. Revue de Géographie du Maroc 10: 47-50.

Cvijić, J. (1900), L’Époque Glaciaire dans la Péninsule des Balkans. Annales de Géographie 9: 359-72.

(1913), The ice age in the Prokletije and surrounding mountains (in Serbian). Glas Srpske Kraljevske Akademije Nauka 91: $1-149$.

(1917), L'Époque Glaciaire dans la Péninsule Balkanique. Annales de Géographie 26: 189-218.

D'Alessandro, L., and Pecci, M. (2001), Rischi da valanga sul Gran sasso d'Itlaia. IV Convegno dei giovani ricercatori di Geologia Applicata, CNR-GNGA, 22-24 Ottobre 1998, Chieti. Memorie della Societa Geologica Italiana 56: 315-20.

- De Sisti, G., D'Orefice, M., Pecci, M., and Ventura, R. (2003), Geomorphology of the summit area of the Gran Sasso d'Italia (Abruzzo, Italy). Geografia Fisica e Dinamica Quaternaria 26: 125-41.

Dansgaard, W., Johnsen, S. J., Clausen, H. B., Dahl-Jensen, D., Gundestrup, N. S., Hammer, C. U., Hvidberg, C. S., Steffensen, J. P., Sveinbjörnsdottir, A. E., Jouzel, J., and Bond, G. (1993), Evidence for general instability of past climate from a 250,000year ice-core record. Nature 364: 218-20.

Daveau, S. (1971), La Glaciation de la Serra de Estrela. Finisterra, Revista portuguesa de geografia. Centro de Estudos Geográficos, Faculdade de Letras, University of Lisbon, 6: 5-40.

(1978), Le périglaciaire d'altitude au Portugal. Colloque sur le Périglaciaire d'altitude du domaine Méditerranéen et Abords. Université Strasbourg, Strasbourg, 63-78.

Diener, C. (1886), Libanon. Grundlinien der physischen Geographie und Geologie von Mittel-Syrien. Vienna.

Dramis, F. and Kotarba, A. (1994), Geomorphological evidences of high mountain permafrost in Central Appenines. Geografia Fisica e Dinamica Quaternaria 17: 29-36.

Dresch, J. and Raynal, R. (1953), Les formes glaciaires et périglaciaires dans le Moyen Atlas. Comptes Rendus Sommaires des Séances de la Société Géologique de France 195-7.

Ehlers, J. (1996), Quaternary and Glacial Geology. Wiley, Chichester.

Erinç, S. (1952), Glacial evidences of climatic variations in Turkey. Geografisker Annaler 34: 89-98.

Fabre, G. and Maire, R. (1983), Néotectonique et morphologénèse insulaire en Grèce: le massif du Mont Ida (Crète). Méditerranée 2: 39-40.

Federici, P. R. (1979), Una ipotesi di cronologia glaciale würmiana, tardo e post- würmiana nell'Appenino Centrale. Geografia Fisica Dinamica Quaternaria 2: 196-202. 
Federici, P. R. (1980), On the Riss glaciation of the Apennines. Zeitschrift für Geomorphologie Ns 24: 111-16.

— and Pappalardo, M. (1995), L'evolutione recente dei ghiacciai delle Alpi Maritime. Geografia Fisica e Dinamica Quaternaria 18: $257-69$.

- and Stefanini, M. C. (2001), Evidences and chronology of the Little Ice Age in the Argentera Massif Italian Maritime Alps. Zeitschrift für Gletscherkunde und Glazialgeologie 37: 35-48.

- Granger, D. E., Pappalardo, M., Ribolini, A., Sapgnolo, M., and Cyr, A. J. (2008), Exposure age dating and Equilibrium Line Altitude reconstruction of an Egesen moraine in the Maritime Alps, Italy. Boreas 37: 245-53.

Fernadez Mosquera, D., Marti, K., Vidal Romani, J. R., and Weigel, A. (2000), Late Pleistocene deglaciation chronology in the NW of the Iberian Peninsula using cosmic-ray produced 21 NE in quartz. Nuclear Instruments and Methods in Physics Research B 172: 832-7.

Fisinger, W. and Ribolini, A. (2001), Late glacial to Holocene deglaciation of the Colle Del Vei Bouc-Colle Del Sabbione Area (Argentera massif, Maritime Alps, Italy-France). Geografia Fisica e Dinamica Quaternaria 24: 141-56.

Florineth, D. and Schlüchter, C. (2000), Alpine evidence for Atmospheric Circulation Patterns in Europe during the Last Glacial Maximum. Quaternary Research 54: 295-308.

Ford, D. and Williams, P. (1989), Karst Geomorphology and Hydrology. Unwin Hyman, London. 601.

French, H. M. (1996), The Periglacial Environment. 2nd edn. Harlow: Longman.

Frochoso, M. and Castañón, J. C. (1995), Comments on 'Glaciers in Picos de Europa, Cordillera Cantábrica, northwest Spain'. Journal of Glaciology 41: 430-2.

Furlan, D. (1977), The climate of Southeast Europe, in C. C. Wallen (ed.), Climates of Central and Southern Europe. Elsevier, Amsterdam, 185-223.

Gabrovec, M. (1998), The Triglav glacier between 1986 and 1998. Geografski zbornik 38: 89-110.

Gams, I. (1994), Changes of the Triglav glacier in the 1955-94 period in the light of climatic indicators. Geografski Zbornik 34: 81-117.

(2001), Notion and forms of contact karst. Acta Carsologica 30/2: 33-46.

García, A. (1996), Contribución al conocimiento glaciar de Sierra Nevada a través de los escritos de los viajeros del siglo XVIII y mediados del XIX, in J. Chacón (ed.), Conferencia Internacional Sierra Nevada. Universidad de Granada - Sierra Nevada 96. Granada, 107-16.

García-Ruiz, J. M., Valero-Garcés, B. L., Martí-Bono, C., and González-Sampériz, P. (2003), Asynchroneity of maximum glacier advances in the central Spanish Pyrenees. Journal of Ouaternary Science 18: 61-72.

Gellatly, A. F., Grove, J. M., and Switsur, V. R. (1992), MidHolocene glacier activity in the Pyrenees. The Holocene 2: 266-70.

- Smiraglia, C., Grove, J. M., and Latham, R. (1994), Recent variations of Ghiacciaio del Calderone, Abruzzi, Italy. Journal of Glaciology 40: 486-90.

Gentileschi, M. L. (1967a), Forme crionivali sul gran Sasso d'Italia. Bollettino della Societa Geografia Italiana 8: 34-61.

- $(1967 b)$, Forme crionivali sulla Maiella. Bollettino della Societa Geografia Italiana 8: 325-50.

Giraudi, C. (2003), Middle Pleistocene to Holocene Appenine Glaciation Italy. Il Quaternario 16: 37-48.
- (2004), The Apennine Glaciations in Italy, in J. Ehlers and P. L. Gibbard (eds.), Quaternary Glaciations-Extent and Chronology. Part I: Europe. Elsevier, Amsterdam, 215-23.

(2005), Middle to Late Holocene glacial variations, periglacial processes and alluvial sedimentation on the higher Apennine massifs (Italy). Quaternary Research 64: 176-84.

and Frezzotti, M. (1997), Late Pleistocene glacial events in the Central Appenines, Italy. Quaternary Research 48: 280-90.

Gómez, A., Schulte, L., García, A., and Palacios, D. (1999), Sobre la eistencia de permafrost en Sierra Nevada. Significado geomorfológico y paleoclimático, in L. Pallí and C. Roqué (eds.), Avances en el estudio del Cuaternario español. AEQUA, Universitat de Girona, 181-6.

- Palacios, D., Ramos, M., Tanarro, L. M., Schulte, L., and Salvador, F. (2001), Location of permafrost in marginal regions: Corral del Veleta, Sierra Nevada, Spain. Permafrost and Periglacial Processes 12: 93-110.

Luengo, E., Tanarro, L. M., Schulte, L., and Ramos, M. (2003), Talus instability in a recent deglaciation area and its relationship to buried ice and snow cover evolution (Picacho del Veleta, Sierra Nevada, Spain). Geografiska Annaler 85A: 165-82.

Gómez-Órtiz, A. and Salvador Franch, F. (1998), Procesos periglaciares actuales en montaña mediterránea. Ideas clave, trabajos de campo y resultados en Sierra Nevada, in A. GómezÓrtiz, F. Salvador Franch, L. Schulte, and A. García Navarro (eds.), Procesos Biofisicos Actuales en Medios Fríos. Estudios Recientes, Publicaciones Universidad de Barcelona, Barcelona, 217-34.

González-Suárez, J. J. and Alonso, V. (1994), Glaciers in Picos de Europa, Cordillera Cantábrica, northwest Spain. Journal of Glaciology 40: 198-9.

Granger, D.E., Spagnolo, M., Federici, P., Pappalardo, M., Ribolini, A. and Cyr, A.J. (2006) Last glacial maximum dated by means of lOBe in the Maritime Alps (Italy). Eos Transactions. American Geophysical Union 87, Fall Meeting Supplement, Abstract H53B-0634.

Grove, A. T. (2001) The 'Little Ice Age' and its geomorphological consequences in Mediterranean Europe. Climatic Change 48: $121-36$.

Grove, J. M. (2004), Little Ice Ages: Ancient and Modern. Routledge, London, i and ii.

and Gellatly, A. F. (1995), Little Ice Age glacier fluctuations in the Pyrénées. Zeitschrift für Gletscherkunde und Glaziolgeologie 31: 199-206.

Güner, Y. and Emre, O. (1983), Erciyes Dağinda Pleyistocen Buzullaşmasi ve Volkanizma ile ilişkisi. Jeomorfoloji Dergisi 11: 23-34.

Gurnell, A. M. and Clark, M. J. (1987), Glacio-fluvial sediment transfer: an alpine perspective. Wiley, Chichester.

Hamlin, R. H. B., Woodward, J. C., Black, S., and Macklin, M. G. (2000), Sediment fingerprinting as a tool for interpreting longterm river activity: the Voidomatis basin, Northwest Greece, in I. D. L. Foster (ed.), Tracers in Geomorphology. Wiley, Chichester, 473-501.

Hérail, G., Hubschman, J. and Jalut, G. (1986), Quaternary glaciation in the French Pyrenees. Quaternary Science Reviews 5: 397-402.

Hewitt, S. (2002), Pleistocene river behaviour and sediment transfer in glaciated catchments of the Mediterranean. Ph.D. thesis, University of Leeds. 
Heybrock, W. (1953), Eiszeitliche Gletscherspuren und heutige Schneeverhältnisse im Zentralgebiet des Hohen Atlas. Zeitschrift für Gletscherkunde und Glazialgeologie 2: 317-21.

(1954), Firnverhältnisse auf Korsika. Zeitschrift für Gletscherkunde und Glazialgeologie 3: 75-8.

Hughes, P. D. (2004), Quaternary glaciation in the Pindus Mountains, northwest Greece. Ph.D. thesis, University of Cambridge. (2007), Recent behaviour of the Debeli Namet glacier, Durmitor, Montenegro. Earth Surface Processes and Landforms 32: 1593-602.

and Woodward, J. C. (2008), Timing of glaciation in the Mediterranean mountains during the last cold stage. Journal of Quaternary Science 23: 575-88.

(2004), Quaternary glaciation in the Atlas Mountains, North Africa, in J. Ehlers and P. L. Gibbard (eds.), Quaternary Glaciation-Extent and Chronology, iii. Asia, Latin America, Africa, Australia, Antarctica. Elsevier, Amsterdam, 255-60.

- (2005), Quaternary glacial records in mountain regions: A formal stratigraphical approach.Episodes 28: 85-92.

$-(2006 a)$, Quaternary glacial history of the Mediterranean mountains. Progress in Physical Geography 30: 334-64.

Woodward, J. C., Gibbard, P. L., Macklin, M. G., Gilmour, M. A., and Smith, G. R. (2006b), Quaternary glacial stratigraphy and geochronology of the Pindus Mountains, Greece. Journal of Geology 114: 413-34.

$-12006 c)$, The last glaciers of Greece. Zeitschrift für Geomorphologie 50: 37-61.

$-12006 d)$, Late Pleistocene glaciers and climate in the Mediterranean region. Global and Planetary Change 50: 83-98.

Imbrie, J., Hays, J. D., Martinson, D. G., McIntyre, A., Mix, A. C., Morley, J. J., Pisias, N. G., Prell, W. L., and Shackleton, N. J. (1984), The orbital theory of Pleistocene climate: support from a revised chronology of the marine ${ }^{18} \mathrm{O}$ record, in A. Berger, J. Imbrie, G. Hays, G. Kukla, and B. Saltzman (eds.), Milankovitch and Climate. Reidel, Dordrecht, 269-306.

Jalut, G., Montserrat, J., Fontunge, M., Delibrias, G., Vilaplana, J., and Juliá, R. (1992), Glacial to interglacial vegetation changes in the northern and southern Pyrenees: deglaciation, vegetation cover and chronology. Quaternary Science Reviews 11: 449-80.

Jiménez-Sánchez, M. and Farias, P. (2002), New radiometric and geomorphologic evidence of Last Glacial maximum older than 18 ka in SW European Mountains: the example of Redes Natural Park Cantabrian Mountains, NW Spain. Geodinamica Acta 15: 93-101.

Jones, A. P. (2000), Late Quaternary sediment sources, storage and transfers within mountain basins using clast lithological analysis: Pineta Basin, central Pyrenees, Spain. Geomorphology 34: 145-61.

Karkanas, P. (2001), Site formation processes in Theopetra cave: a record of climatic change during the Late Pleistocene and early Holocene in Thessaly, Greece. Geoarchaeology 16: 373-99.

Kelletat, D. (1969), Verbreiung und Vergesellschaftung Rezenter Periglazialerscheinungen im Apennin. Goettinger Geographische Abhandlungen 48: 1-114.

Kotarba, A., Hercman, H., and Dramis, F. (2001), On the age of Campo Imperatore glaciations, Gran Sasso Massif,
Central Italy. Geografia Fisica e Dinamica Quaternaria 24: 65-9.

Krajick, K. (2004), All downhill from here? Science 303: 1600-2. Kuhleman, J., Frisch, W., Székely, B., Dunkl, I., Danišík, M., and Krumei, I. (2005), Würmian maximum glaciation in Corsica. Austrian Journal of Earth Sciences 97: 68-81.

Kurter, A. (1991), Glaciers of the Middle East and Africa-Glaciers of Turkey, in R. S. Williams and J. G., Ferrigno (eds.), Satellite Image Atlas of Glaciers of the World. United States Geological Survey Professional Paper 1386-G-1: 130.

and Sungur, K. (1980), Present glaciation in Turkey. International Association of Hydrological Sciences 126: 155-60.

Lamb, H. H. (1977), Climate: Present, Past and Future, ii. Climatic History and the Future. Methuen, London.

Lebourg, T., Fabre, R., Clement, B., and Frappa, M. (2003), Highmountain landslides in the Atlantic Pyrenees: their relationship with the geology and geomorphology. Bulletin of Enginneering Geology and the Environment 62: 221-9.

Letsch, K. (1956), Firnverhältnisse auf Korsika. Zeitschrift für Gletscherkunde und Glazialgeologie 3: 268.

Lewin, J., Macklin, M. G., and Woodward, J. C. (1991), Late Quaternary fluvial sedimentation in the Voidomatis basin, Epirus, northwest Greece. Quaternary Research 35: 103-15.

Liedtke, H. (1962), Eisrand und Karstpoljen am Westrand Lukavica-Hochfläche. Erdkunde 16: 289-98.

Louis, H. (1926), Glazialmorphologishche Beobachtungen im albanischen Epirus. Zeitschrift der Gesellschaft für Erdkunde 398-409.

Magaš, D. (2002, Natural-geographic characteristics of the Boka Kotorska area as the basis of development. Geoadria 7/1: 51-81.

Marino, A. (1992), Nota preliminaire sul fenomeno glaciologico della Gretta del Gelo (Monte Etna). Geografia Fisica Dinamica Quaternaria 15: 127-32.

Marjanac, L. and Marjanac, T. (2004), Glacial history of the Croatian Adriatic and Coastal Dinarides, in J. Ehlers and P. L. Gibbard (eds.), Quaternary Glaciation-Extent and Chronology. Part I: Europe. Elsevier, Amsterdam, 19-26.

Marovic, M. and Markovic, M. (1972), Glacial morphology of the Durmitor Mt. wider area (in Serbian). Geoloski anali Balkanskog poluostrva 37: 37-48.

Martinson, D. G., Pisias, N. G., Hays, J. D., Imbrie, J., Moore, T. C., and Shackleton, N. J. (1987), Age dating and the orbital theory of the ice ages: development of a high resolution 0 300,000 year chronostratigraphy. Quaternary Research 27: $1-29$.

Menkovic, L., Markovic, M., Cupkovic, T., Pavlovic, R., Trivic, B., and Banjac, N. (2004), Glacial Morphology of Serbia Yugoslavia, with comments on the Pleistocene Glaciation of Montenegro, Macedonia and Albania, in J. Ehlers and P. L. Gibbard (eds.), Quaternary GlaciationsExtent and Chronology. Part I: Europe. Elsevier, Amsterdam, 379-84.

Messerli, B. (1967), Die eiszeitliche und die gegenwartige Vertgletscherung im Mittelemeeraum. Geographica Helvetica 22: $105-228$.

(1980), Mountain glaciers in the Mediterranean area and in Africa. World Glacier Inventory. World Glacier Inventory, International Association of Hydrological Sciences 126: $197-211$.

Michelier, P. L. (1887), Rapport sur les variations des glaciers des Pyrénées. Annales du bureau Central Météorologique du France 1: $1-235$. 
Mistardis, G. (1952), Recherches glaciologiques dans les parties supérieures des Monts Oeta et Oxya Grèce Centrale. Zeitschrift für Gletscherkunde und Glazialgeologie 2: 72-9.

Nicod, J. (1968), Premières recherches de morphologie karstique dans le massif du Durmitor. Meditéranée 3: 187-216.

Niculescu, C. (1915), Sur les traces de glaciation dans le massif Smolica chaîne du Pinde méridional. Bulletin de la Section Scientifique de l'Academie Roumaine 3: 146-51.

Ohmura, A., Kasser, P., and Funk, M. (1992), Climate at the equilibrium line of glaciers. Journal of Glaciology 38: $397-411$.

Palacios, D., de Andrés, N., and Luengo, E. (2003), Distribution and effectiveness of nivation in Mediterranean mountains: Peñalara (Spain). Geomorphology 54: 157-78.

-Marcos, J., Andres, N., and Vazquez, L. (2007), Last glacial maximum and deglaciation in central Spanish mountains. Geophysical Research Abstracts 9: 05634.

Palgrave, W. G. (1872), Vestiges of the glacial period in northeastern Anatolia. Nature 5: 444-5.

Pallàs, R., Rodés, Á., Braucher, R., Carcaillet, J., Ortuño, M., Bordonau, J., Bourlès, D., Vilaplana, J. M., Masana, E., and Santanach, P. (2007), Late Pleistocene and Holocene deglaciation in the Pyrenees: a critical review and new evidence from ${ }^{10} \mathrm{Be}$ ages, south-central Pyrenees. Quaternary Science Reviews 25 : 2937-63.

Palmentola, G., Boenzi, F., Mastronuzzi, G., and Tromba, F. (1990), Osservazioni sulle tracce glaciali del M. Timfi, catena del Pindo (Grecia). Geografia Fisica e Dinamica Quaternaria 13: 165-70.

- Baboci, K., Gruda, G., and Zito, G. (1995), A note on rock glaciers in the Albanian Alps. Permafrost and Periglacial Processes 6: 251-7.

Pappalardo, M. (1999), Remarks on the present-day condition of the glaciers in the Italian Appenines. Geografia Fisica e Dinamica Quaternaria 18: 257-69.

Pechoux, P. Y. (1970), Traces of glacial action in the Mountains of Central Greece. Revue de Géographie Alpine 58: 211-24.

Penck, A. (1885), La Période glaciaire dans les Pyrénées. Bulletin de la Societe d'Histoire Naturelle de Toulouse 19: 105-200.

(1900), Die Eiszeit auf der Balkanhalbinsel. Globus 78: 133-78.

Ponel, P., Andrieu-Ponel, V., Parchoux, F., Juhasz, I., and De Beaulieu, J.-L. (2001), Late-glacial and Holocene highaltitude environmental changes in Vallée des Merveilles AlpesMaritimes, France: insect evidence. Journal of Quaternary Science 16: 795-812.

Poser, J. (1957), Klimamorphologische Probleme auf Kreta. Zeitschrift für Geomorphologie 2: 113-42.

Pumpelly, R. (1859), Sur quelques glaciers dans l'île de Corse. Bulletin de la Société Géologique de France 17: 78.

Raynal, R. (1952), Quelques examples de l'action du froid et le neige sur les formes du relief au Maroc. Notes Marocaines 2: 14-18.

—Dresch, J., and Joly, F. (1956), Deux exemples régionaux de glaciation Quaternaire au Maroc: Haut Atlas Oriental, Moyen Atlas Septentrional. IV Congrès INQUA, Rome-Pisa, 1953 105-17.

Ribolini, A. (1996), Note geomorfologiche sull'alta Valle del Sabbione e sulla Val'd'Ischietto (Gruppo dell'Argentera, Alpi Marittime). Geografia Fisica e Dinamica Quaternaria 19: 79-91.
- (1999), Areal distribution of rock glaciers in the Argentera massif (Maritime Alps) as a tool for recent glacial evolution reconstruction. Geografia Fisica e Dinamica Quaternaria 22: 83-6.

and Fabre, D. (2006), Permafrost existence in rock glaciers of the Argentera Massif, Maritime Alps, Italy. Permafrost and Periglacial Processes 17: 49-63.

Robinson, D. A. and Williams, R. B. G. (1992), Sandstone weathering in the High Atlas, Morocco. Zeischrift für Geomorphologie 36: 413-29.

Roth von Telegd, K. (1923), Das albanisch-montenegrinische Grenzgebiet bei Plav (Mit besonderer Berücksichtigung der Glazialspuren), in E. Nowack (ed.), Beiträge zur Geologie von Albanien. Neues Jahrbuch für Mineralogie 1. Schweizerbart, Stuttgart, 422-94.

Sahsamanoglu, H. S. (1989), Mount Olympus Summer Snowfall. International Journal of Climatology 9: 309-19.

Sancho, L. G., Palacios, D., De-Marcos, J., and Valladares, F. (2001), Geomorphological significance of lichen colonization in a present snow hollow: Hoya del cuchillar de las navajas, Sierra de Gredos (Spain). Catena 43: 323-40.

Sarıkaya, A. M., Çiner, A., and Zreda, M. (2003), Late Quaternary glaciation of Erciyes volcano, central Turkey. XVI INQUA Congress, Reno, Nevada 23-30 July 2003, Abstracts with Programmes, Abstract 40-4: 144.

Zreda, M., Çiner, A., and Zweck, C. (2008), Cold and wet Last Glacial Maximum on Mount Sandlras, SW Turkey, inferred from cosmogenic dating and glacier modelling. Quaternary Science Reviews 27: 769-80.

Sawicki, R. von. (1911), Die eiszeitliche Vergletscherung des Orjen in Süddalmatien. Zeitschrift für Gletscherkunde 5: 339-50.

Seret, G., Dricot, J., and Wansard, G. (1990), Evidence for an early glacial maximum in the French Vosges during the last glacial cycle. Nature 346: 453-6.

Serrano, E., Agudo, C., and Pison, E. M. (1999), Rock glaciers in the Pyrenees. Permafrost and Periglacial Processes 10: 101-6.

——— and González Trueba, J. J. (2002), La deglaciación de la laalta montaña. Morphología, evolución y fases morfogenéticas glaciares en el macizo del Posets (Pirineo Aragonés). Revista Cuaternario y Geomorfologia 16: 111-26.

Serrat, D. (1979) Rock glaciers and moraine deposits in the eastern Pyrenees, in C. Schlüchter (ed.), Moraines and Varves. Balkema, Rotterdam, 93-100.

— and Ventura, J. (1993), Glaciers of the Pyrenees, Spain and France, in R. S. Williams and J. G. Ferrigno (eds.), Satellite Image Atlas of Glaciers of the World. United States Geological Survey Professional Paper 1386-E-2: 49-61.

Sestini, A. (1933), Tracce glaciali sul Pindo epirota. Bollettino della Reale Società Geografica Italiano 10: 136-56.

Sibrava, V., Bowen, D. Q., and Richmond, G. M. (eds.) (1986), Quaternary Glaciations in the Northern Hemisphere. Quaternary Science Reviews 5: 1-511.

Sifrer, M. (1963) New findings about the glaciation of Triglav. Geografiski zbornik 8: 157-210.

Simon, M., Garcia, I., Cabezas, O., Sanchez, S., and Gómez-Ortiz, A. (1994), Terrenos configurados ordenados en la alta montana mediterranea. Pirineos 144: 71-85.

Smart, P. L. (1986), Origin and development of glacio-karst closed depressions in the Picos de Europa, Spain. Zeitschrift für Geomorphologie Ns 30: 423-43. 
Smith, G. W., Nance, R. D., and Genes, A. N. (1997), Quaternary Glacial History of Mount Olympus. Geological Society of America Bulletin 109: 809-24.

Smith, K. (2004), Trekking in the Atlas Mountains. Cicerone, Milnthorpe.

Toro, M., Flower, R. J., Rose, N. L., and Stevenson, A. C. (1993), The sedimentary record of the recent history in a high mountain lake in central Spain. Verhandlungen Internationale Vereinigung Limnologie 25: 1108-12.

Tzedakis, P. C. (1994), Vegetation change through glacialinterglacial cycles: a long pollen sequence perspective. Philosophical Transactions of the Royal Society of London B345: 403-32.

—Lawson, I. T., Frogley M. R., Hewitt G. M., and Preece R. C. (2002) Buffered Tree Population Changes in a Quaternary Refugium: Evolutionary Implications. Science 297: 2044-7.

-Frogley, M. R., Lawson, I. T., Preece, R. C., Cacho, I., and de Abreu, L. (2004), Ecological thresholds and patterns of millennial-scale climate variability: The response of vegetation in Greece during the last glacial period. Geology 32: 109-12.

Vieira, G., Ferreira, A. B., Mycielska-Dowgiallo, E., Woronko, B., and Olszak, I. (2001), Thermoluminescence Dating of Fluvioglacial Sediments Serra da Estrela, Portugal. V REQUI - I CQPLI, Lisbon, 23-7 July 2001, 85-92.

Mora, C., and Ramos, M. (2003), Ground temperature regimes and geomorphological implications in a Mediterranean mountain (Serra da Estrela, Portugal). Geomorphology 52: $57-72$.

Waltham, A. C. (1978), The Caves and Karst of Astraka, Greece. Transactions of the British Cave Research Association 5: $1-12$.

Woodward, J. C. (1997), Late Pleistocene rockshelter sedimentation at Megalakkos, in G. N. Bailey (ed.), Klithi: Palaeolithic
Settlement and Quaternary Landscapes in Northwest Greece, ii. Klithi in its Local and Regional Setting. MacDonald Institute for Archaeological Research, Cambridge, 377-93.

Lewin, J., and Macklin, M. G. (1992), Alluvial sediment sources in a glaciated catchment: the Voidomatis basin, northwest Greece. Earth Surface Processes and Landforms 16: 205-16.

(1995), Glaciation, river behaviour and the Palaeolithic settlement of upland northwest Greece, in J. Lewin, M. G. Macklin, and J. C. Woodward (eds.), Mediterranean Quaternary River Environments. Balkema, Rotterdam, 115-29. and Smith, G. R. (2004), Pleistocene Glaciation in the Mountains of Greece, in J. Ehlers and P. L. Gibbard (eds.), Quaternary Glaciations - Extent and Chronology. Part I: Europe. Elsevier, Amsterdam, 155-73.

- Hamlin, R. H. B., Macklin, M. G., Hughes, P. D., and Lewin, J. (2008), Glacial activity and catchment dynamics in northwest Greece: Long-term river behaviour and the slackwater sediment record for the last glacial to interglacial transition. Geomorphology 101: 44-67.

World Glacier Monitoring Service (2003), Glacier Mass Balance Bulletin $7<$ http://www.geo.unizh.ch/wgms/>, accessed 23 October 2008 .

(2005), Glacier Mass Balance Bulletin 8 <http://www.geo. unizh.ch/wgms/>, accessed 23 October 2008.

Wright, H. E. (1962), Pleistocene glaciation in Kurdistan. Eiszeitalter und Gegenwart 12: 131-64.

Xoplaki, E., Maheras, P., and Luterbacher, J. (2001), Variability of climate in meridional Balkans during the periods 1675-1715 and 1780-1830 and its impact on human life. Climatic Change 48: 581-615.

Yılmaz, Y., Güner, Y., and Şaroğlu, F. (1998), Geology of the Quaternary volcanic centres of the east Anatolia. Journal of Volcanology and Geothermal Research 85: 173-210.

\section{This chapter should be cited as follows}

Hughes, P. D. and Woodward, J. C. (2009), Glacial and periglacial environments, in J. C. Woodward (ed.), The Physical Geography of the Mediterranean. Oxford University Press, Oxford, 353-383. 
12-Woodward-C12 9780199268030-Jamie-Woodward （Typeset by SPi, Chennai) 384 of $384 \quad$ April 15, 2009 13:21 